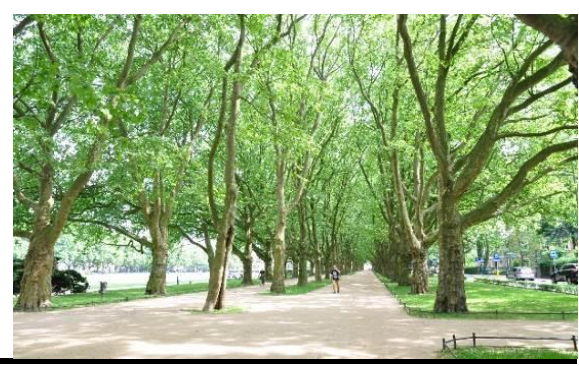

DOI: 10.21005/pif.2021.47.C-02

\title{
LIMITED SPACE FOR TREES IN THE URBAN PLANNING OF THE CITY (ON THE EXAMPLE OF SELECTED LOCATIONS IN SZCZECIN AND GOLENIÓW)
}

\author{
OGRANICZONA PRZESTRZEŃ DLA DRZEW W ZAGOSPODAROWANIU \\ URBANISTYCZNYM MIASTA (NA PRZYKŁADZIE WYBRANYCH LOKALIZACJI \\ W SZCZECINIE I GOLENIOWIE)
}

\section{Paweł Nowak}

PhD Eng. Landscape architect

Author's Orcid number:0000-0002-3526-1062

West Pomeranian University of Technology in Szczecin

Faculty of Environmental Management and Agriculture

Chair of Landscape Architecture

\begin{abstract}
This paper presents a study on the introduction of trees into urban space after 1960 on the example of Szczecin and Goleniów, Selected area types located in downtown areas such as: front gardens, greenery strips along streets, and trees lining streets, were observed over a period of five years and analysed. This paper is also intended to present the significant problem of trees dying in downtown areas. Current methods of alleviating the difficult situation of trees in the city were also presented.
\end{abstract}

Keywords: trees in the city, urban space, environmental protection, greenery strip, tree replanting.

\section{STRESZCZENIE}

W artykule przedstawiono badania związane z wprowadzaniem drzew w przestrzeń miejską po roku 1960, na przykładzie miast: Szczecina i Goleniowa. Wybrane obszary zlokalizowane w centrum miast, takie jak: przedogródek, pas zieleni wzdłuż ulicy oraz drzewa przy ulicach zostały poddane obserwacjom na przestrzeni pięciu lat oraz analizom. Artykuł ma na celu przedstawić bardzo ważny problem zamierania drzew w centrum miast. Wskazano również aktualne metody rozwiązania problemu trudnej sytuacji drzew w mieście.

Słowa kluczowe: drzewa w mieście, przestrzeń miejska, ochrona przyrody, pas zieleni, przesadzanie drzew. 


\section{INTRODUCTION}

Constraints on the maintenance and planting of greenery are present in both large and mediumsized cities. There are many causes behind this state of affairs, but the set of factors in question, that produces a specific, negative outcome, can be either minimised or addressed. Solutions should be sought. There is abundant evidence that trees improve living conditions in cities. There is a countless number of books and papers written on this subject. At present, there is a need to investigate the causes behind the low amount of greenery. Why is it not increasing in most urban agglomerations, and why is it even irretrievably disappearing from many places. It appears that it has become a widespread opinion that trees cannot grow to impressive sizes in urban conditions, either due to air pollution, the presence of particulate matter, salinity or other factors. However, as comparative analyses show, greenery can be found to be in a poorer condition in smaller cities or in places distant from downtown areas than the greenery along major transport arterials. Why is it so? What can be done to change this?

\section{STATE OF THE ART - TREES IN THE CITYSCAPE AROUND THE WORLD}

In 2009, during the 10th National Street Tree Symposium in Australia, trees were seen as providers of numerous environmental benefits to cities, especially shade (Ely, 2009, p. 87-98). In addition, it was noted that citizens greatly prized the visual benefits of trees. These benefits were contrasted with a series of problems arising from trees clashing with municipal infrastructure. Cities often try to excuse the low number of trees planted by citing the desire for greater focus and more effective management, achieved via a lower amount of greenery that needs to be cared for. They often complained about a lack of space and constraints arising from the lack of water and the development of any remaining open space in the city. The solution to the difficult situation of water shortages is directing stormwater in the direction of green areas. A combination of two factors is crucial: green assets and the application of available knowledge. Ely concluded that a cohesive approach to organising space with a plan is needed, in cooperation with a number of specialist fields, so as to prevent future situations wherein greenery becomes the least important element.

Ferrini et al. noted easing climate change using trees (Ferrini et al., 2014 p. 243). When planting trees, three crucial factors need to be accounted for, namely ensuring that suitable plants are placed at a specific place, at a specific time, and using suitable techniques. Overall, these factors, which are affected by climate change to some degree, can be divided into three major categories: design, location and greenery maintenance. The factors that need to be accounted for during the selection of street or park trees are the needs of a given species and its reaction to cutting, a tree's outline, resistance to disease, insect pests, soil adaptation, sun or shade tolerance, and its origin and variety.

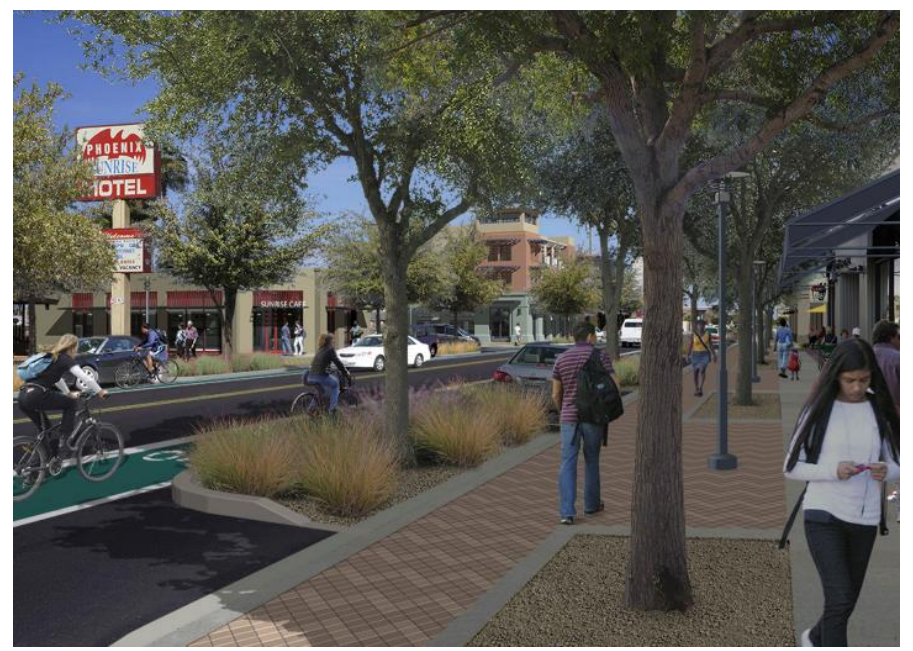

Fig. 1. Modernisation design of Van Buren Street in Phoenix, US. Source: Crabtree P. 2020, p. 9.

Ryc. 1. Projekt modernizacji ulicy dla Van Buren Street w Phoenix, USA. Źródło: Crabtree P. 2020, p.9. 
Civil engineer Paul Crabtree presented his design of the modernisation of Van Buren Street in Phoenix (Crabtree P. 2020, p. 9), as seen in Fig. 1.

Trees are an integral part of any city's urban plan. City trees in parks, in courtyards, along streets and on plots have been an element of urban layouts and landscape architecture for centuries (Arnold, 1980). The author of Trees in Urban Design encouraged landscape architects and urban planners to use trees not only for decoration, but also as a living material with which to build and reinforce urban spaces. He also highlighted that urbanisation has a tendency to grow (Lüttge, Buckeridge, 2020, p. 1), and the links between green space and human psychological health are significant (Beyer K. et al., 2014).

\section{CURRENT STATE (SZCZECIN AND GOLENIÓW)}

In the years 1806-1813, during a period of French occupation, Szczecin was given a distinctive spatial layout that remains legible in its urban fabric to this day. It is formed by circular squares and streets that radially extend from them, with a clearly demarcated space for trees. This layout provided trees with a suitable area for development and maintaining health. After 1960, many socalled 'panel block' buildings were built in the city centre, with green areas (mostly lawns) around them. In recent years, considerable demand for parking spaces appeared, which resulted in the mass reduction of green areas and their replacement with paved surfaces. A similar situation has been observed in many cities, including smaller ones, such as Goleniów (West Pomeranian Voivodeship). The course of these actions severely limits the free development of existing plants and does not bode well for the future. Urgent measures need to be taken to improve this situation, in which impressive, several-decades-old trees are dying and are removed from urban space.

Szczecin is described as a 'city of greenery', as evidenced by its residence repeating this statement quite often. The city currently has 16 parks, 93 public gardens and almost 5 thousand square metres of flower beds (ZUK, 2021). Kasprowicza Park is the city's most well-known and popular green location, both among residents and tourists. Jasne Błonia square, where numerous London planes (monuments to nature) were planted along Szymanowskiego and Ogińskiego streets, forming beautiful double alleys (Fig. 2) also deserves recognition. Another green place are the Chrobry Embankments, built at the turn of the twentieth century, with oaks growing along Zygmunta Starego and Szczerbcowa streets. Near the Chrobry Embankments is Żeromskiego Park. The largest forest park located within the city limits is Arkoński Forest Park. As written by Czekiel-Świtalska: 'In Szczecin, there are $64,7 \mathrm{~m}^{2}$ of recreational greenery per resident, in Warsaw there are $47,2 \mathrm{~m}^{2}$, while in Krakow there are 35,8 $\mathrm{m}^{2}$ (Czekiel-Świtalska, 2010, p. 165-182).

Fig. 2. View of Jasne Błonia square in Szczecin, plane alley. Source: Phot. author.

Ryc. 2. Widok na plac Jasne Błonia w Szczecinie, aleja platanowa. Źródło: fot. autor.

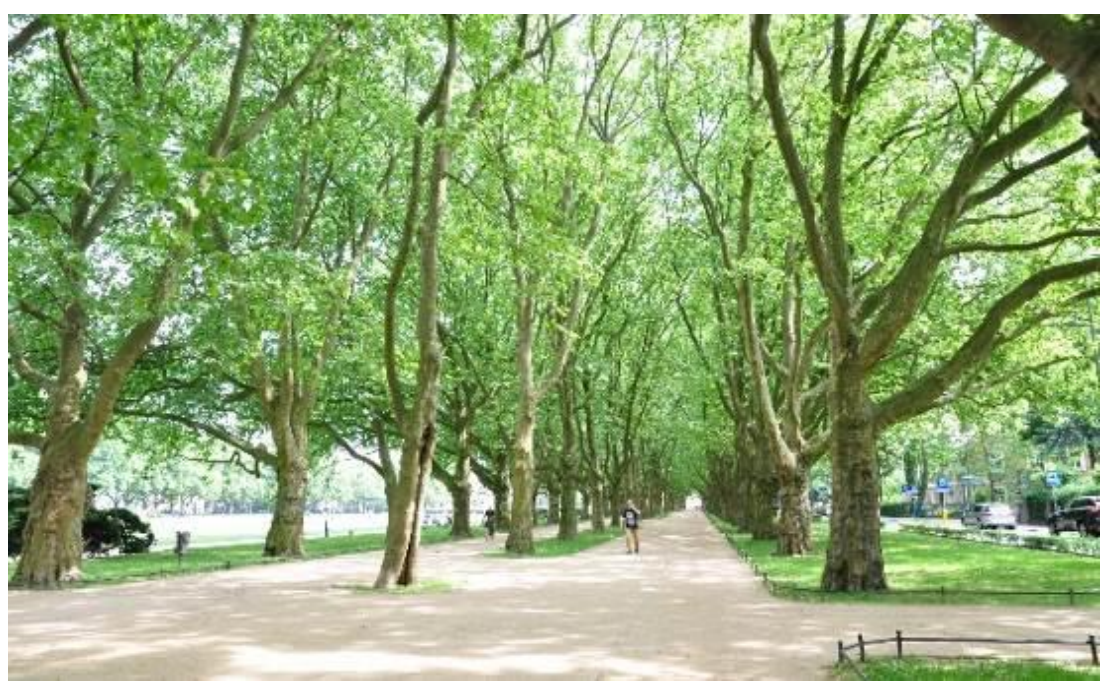


In Goleniów, it can be observed that the city has numerous parks that used to be cemeteries. The largest city park is 750-lecia Park (present-day name, Park of the Thirty-Year Anniversary of the People's Republic of Poland), which is a former German and Jewish cemetery. We can also list the Park that used to be an Evangelical cemetery near the Church of St George, the Park that used to be an Evangelical cemetery at Wojska Polskiego Street (Polińska, Gaj, 2016) and Paderewskiego Park near the Goleniów Forest Inspectorate building at Parkowa Street.

\section{OBJECT OF STUDY}

The object of study consists of city greenery sites located in the cities of Szczecin and Goleniów, which include categories like: city frontal gardens, housing complex greenery and street greenery. Examples of sites that were observed and analysed are: the frontal garden at 21 Monte Cassino Street in Szczecin, trees in the area managed by the Homeowners Associations at Stowackiego Street in Goleniów and trees at Konstytucji 3 Maja Street in Goleniów. The selected areas of city greenery were studied over a period between July 2017 and March 2021. For comparison, existing greenery strips along the main transport arterial in Szczecin, namely Bolesława Krzywoustego Street and a greenery strip near a shopping centre in Szczecin.

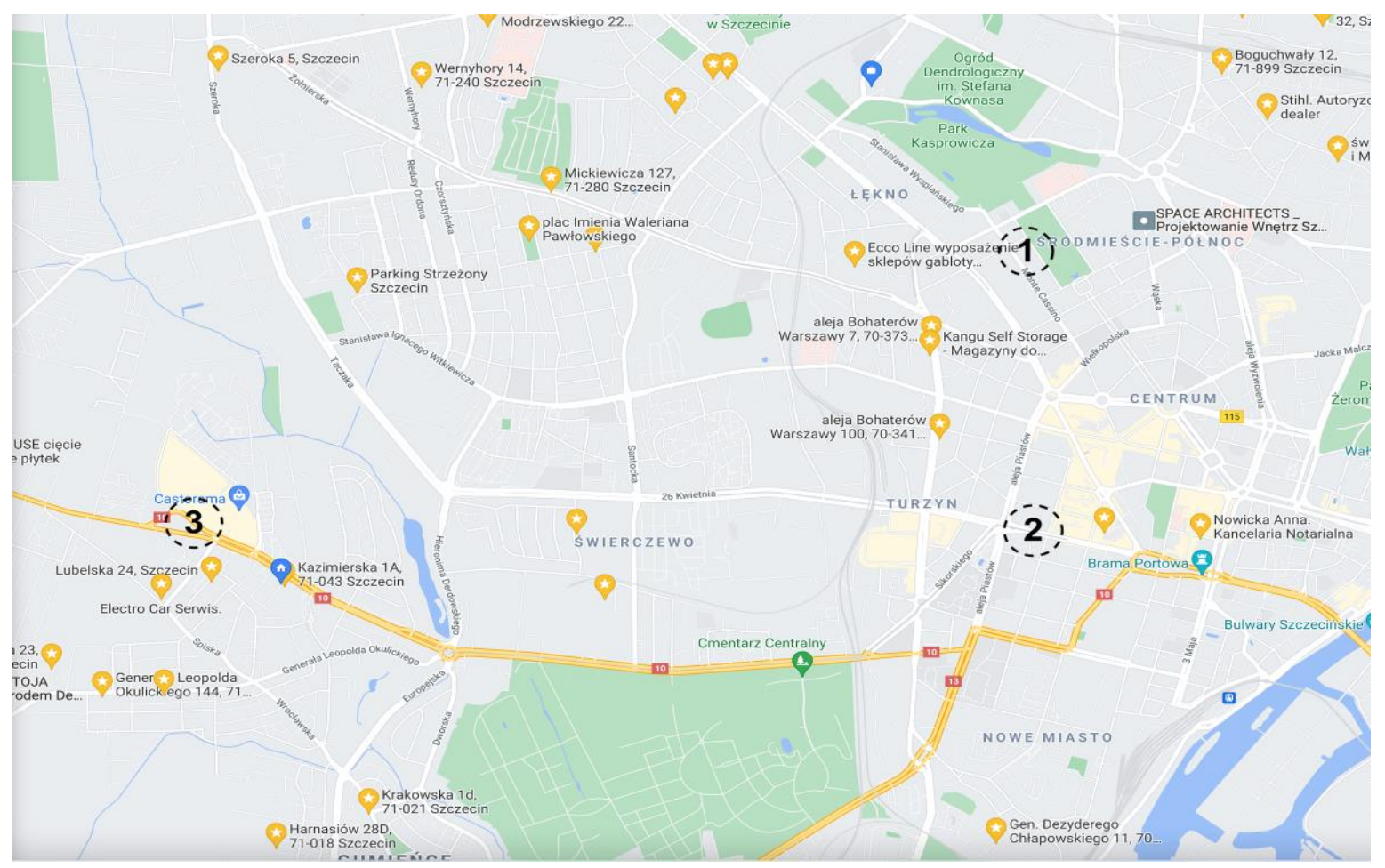

Fig. 3. Map of Szczecin with the sites analysed marked: no. 1: frontal garden at 21 Monte Cassino Street, no. 2: Bolesława Krzywoustego Street, no. 3. Greenery near a shopping centre. Source: original work.

Ryc. 3 Mapa Szczecina z lokalizacją obiektów: nr 1. przedogródek przy ul. Monte Cassino 21, nr 2. ul. Bolesława Krzywoustego, nr 3. teren zieleni przy centrum handlowym. Źródło: opracowanie własne.

\section{GOAL OF THE STUDY AND METHODOLOGY}

The goal of this study was to assess the current state of selected greenery sites in terms of the function of greenery that they should fulfil in the city, with a specific focus on the state of preservation of existing trees. The study focused on identifying whether the standards of maintaining and 
preserving trees in the city were maintained and what were the consequences of not applying them. This paper is intended to present the crucial problem of trees dying in city centres, in the literal sense. The paper also highlights solutions to the problem of the difficult situation of trees in the city. The study made use of research and field observations and a method of comparing specific cases of previously mentioned greenery sites, performed over a period of time, i.e., in the years 2017-2021.

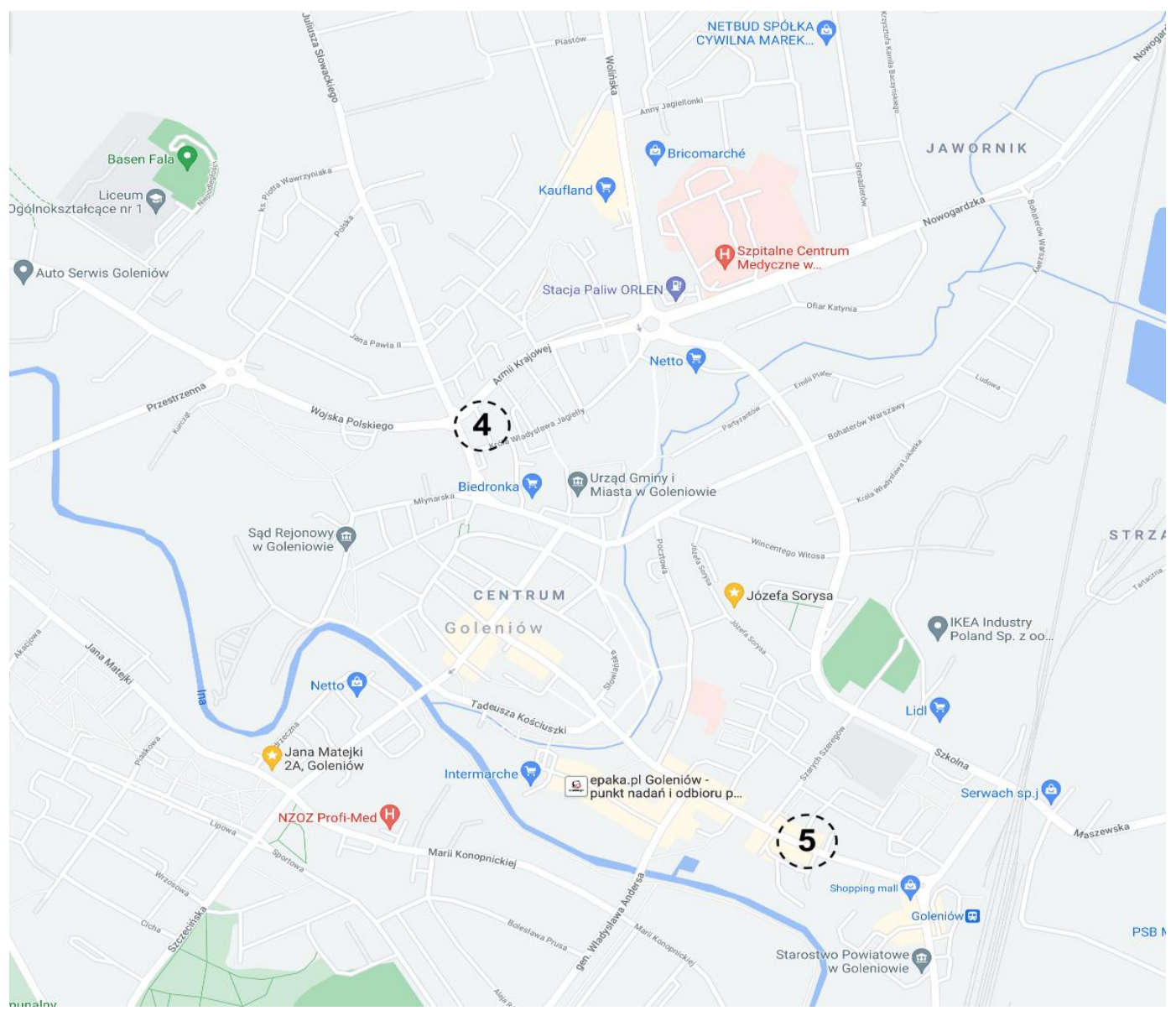

Fig. 4. Map of Goleniów with the sites analysed marked: no. 4: the area managed by the Homeowners' Association at Słowackiego Street, no. 5: Konstytucji 3 Maja Street. Source: original work.

Ryc. 4 Mapa Goleniowa z lokalizacją obiektów; nr 4. teren Wspólnoty Mieszkaniowej przy ul. Słowackiego, nr 5. ul. Konstytucji 3 Maja. Żródło: opracowanie własne.

\section{ANALYSIS OF REGULATIONS AND ACTS PERTAINING TO THE PRESERVATION OF TREES IN CITIES ON THE EXAMPLE OF SZCZECIN}

At present (2021), a tree removal permit is required for trees whose trunk circumference, measured at a height of $5 \mathrm{~cm}$, exceeds: $80 \mathrm{~cm}$ - in the case of poplars, willows, boxelder maples and silver maples; $65 \mathrm{~cm}$ - in the case of horse chestnuts, black locusts and London planes; $50 \mathrm{~cm}$ - in the case of all other tree species. The Environmental Protection Act stipulates that issuing a tree or bush removal permit with circumferences in excess of what is written in the act is conditional upon replacement plantings, and thus a postponement of issuing payment, for a period of three years after the date specified in the replacement planting permit. Officials suggest the number of plants to be planted, their species, the date of planting and trunk circumference (Environmental 
Protection Act). Additional requirements include specific plant material properties, as this material should be healthy, possess a straight trunk (typically with a circumference of at least 14-16 cm as measured at a height of $100 \mathrm{~cm}$ ). This applies to trees, while bush seedlings should be 2-3 years of age, with at least 5-7 well-developed main shoots with branching typical for their variety.

The organ suitable for issuing the permit obligates the applicant to submit a declaration of planting replacement plants within 14 days of said planting, that is to include a greenery plan (in paper form). As stipulated, further maintenance of the trees and bushes planted is to be performed by the applicant and is to last for 3 years.

Due to the regulations presented above, a need to introduce changes in the administration of Szczecin's greenery revealed itself, namely the planting of new trees following a generally laid out planting plan and a later plant maintenance plan. This is why the President of the City of Szczecin has recently enacted a dedicated Ordinance. The Ordinance concerned the Maintenance, protection and development of Szczecin's green areas and the duties contributing to their implementation. When comparing the situation in other Polish cities, such as Warsaw and Wrocław, similar ordinances were signed already in 2016. Why did this take place so late in Szczecin?

\section{CASE I: URBAN FRONT GARDEN - THE ESSENCE OF THE PROBLEM WAS IDENTIFIED}

The 2025 Szczecin Development Strategy (Strategia Rozwoju Szczecina 2025, 2011) that is being implemented by the President features the motto 'Green City', and plans to combine and focus attention on three major areas: air, water and wildlife. As a part of the PLATAN programme that is implemented by the City of Szczecin, more than a dozen thousand trees and bushes were planted in the years 2018-2019. However, if one accounts for the number of trees removed in 2017 after the liberalisation of the Environmental Protection Act, the problem that private property owners have with large trees becomes evident. Such trees, due the strength of their growth, final height, or crown width, are not adapted to the specificity of their current habitat in any way. Ignorance of the consequences of planting trees that form wide crowns - which becomes evident only after more than a decade - in cramped urban spaces, leads to a tree removal permit. Trees with picturesque, wide crowns should have ample room to grow and can only live to an age of several hundred years under such conditions (Bugała, 2000). Meanwhile, older tree specimens that have already been growing for several decades have limited room for root development due to the compaction of the soil around the tree and the resulting lack of access to air and water (Bugała et al., 1984). The photographs below show the clash that occurred between an old tree and a historical fence at Monte Cassino Street in Szczecin (Fig. 5, Fig. 6).

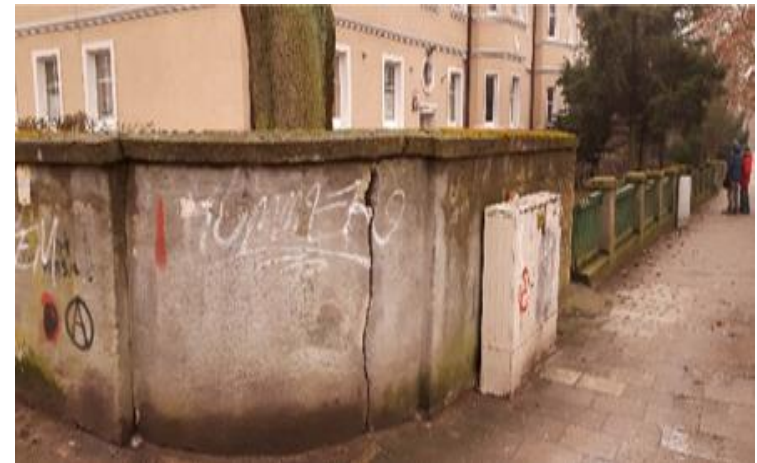

Fig. 5. Front garden at 21 Monte Cassino Street, September 2020. Source: author.

Ryc. 5. Przedogródek przy ul. Monte Cassino 21, wrzesień 2020 r. Źródło: autor.

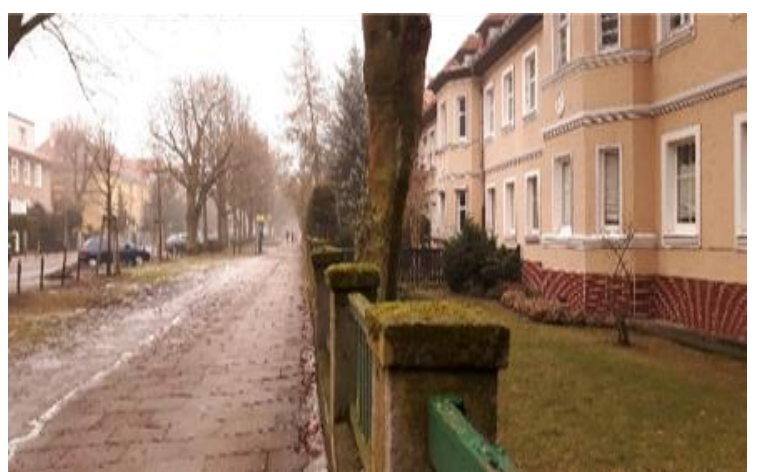

Fig. 6. Front garden at 21 Monte Cassino Street, September 2020. Source: author.

Ryc. 6. Przedogródek przy ul. Monte Cassino 21, wrzesień 2020 r. Źródło: autor. 


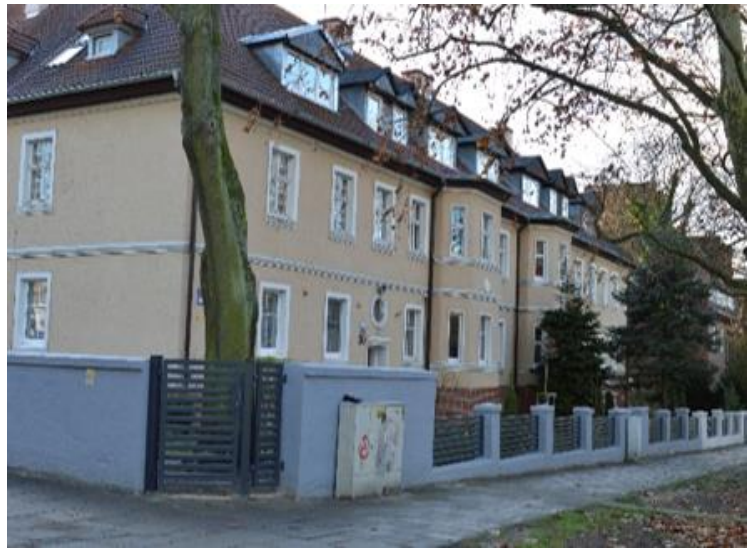

Fig. 7. Front garden at 21 Monte Cassino Street, present state, as seen in 2021. Source: author.

Ryc. 7. Przedogródek przy ul. Monte Cassino 21, stan obecny 2021. Źródło: autor.

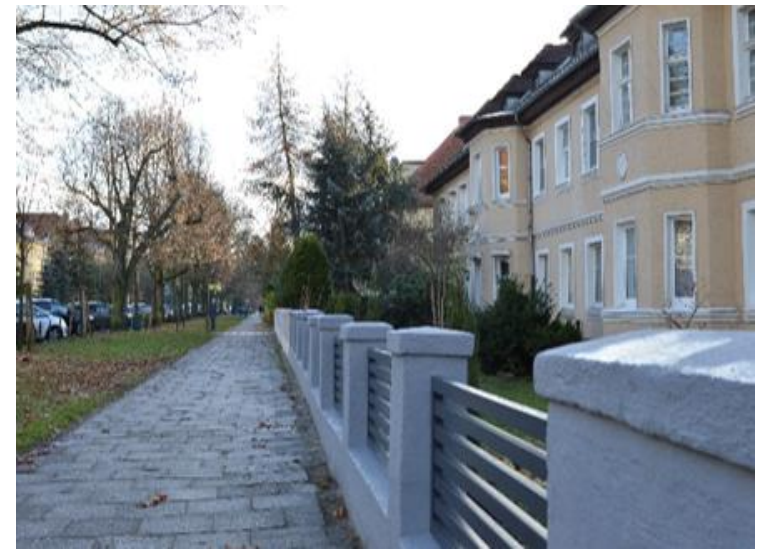

Fig. 8. Front garden at 21 Monte Cassino Street, present state, as seen in 2021. Source: author.

Ryc. 8. Przedogródek przy ul. Monte Cassino 21, stan obecny 2021. Źródło: autor.

In the case of Monte Cassino Street in Szczecin, the problem stemmed from two large Norway maples that had been planted too close to the line of an old fence. Reports by the residents of the community indicated that the trees cast too much shade and shed massive amounts of five-lobed leaves during autumn, while their roots damaged the pavement surface and the old fence. The residents filed applications for the removal of the trees to the Department of Environmental Protection of the Office of the Marshal of the West Pomeranian Voivodeship at Starzyńskiego Street. Over the course of administrative proceedings, by decision of the Office, a permit for the removal of one of the trees was issued. It was the maple that cast the most shade and blocked most of the light from reaching residential spaces. It also caused damage to the pavement and its trunk had been harmed by lightning, which posed a threat. The tree removal permit issued also specified the number of replacement plants, whose species, variety and trunk circumference were precisely listed in the planting design. The decision to remove the tree was followed through, and the old fence was renovated. The design accounted for the final height of the proposed tree species so that they would not dominate the space of the front garden. The Norway maple, as the second tree featured in the tree removal application, was located in the corner of the fence, did not cast shade on the building's windows, but did cause damage to the old fence wall with its growing root system. Apart from the application to remove the two trees, the residents also expressed a willingness to participate in the Szczecin's green front gardens programme. 'The objective of the PROGRAMME is to improve the image of the City of Szczecin by enhancing the conditions and aesthetics of building surroundings, including the renovation of existing green areas - FRONT GARDENS' (ZBILK, 2017). In the application, the site of the second tree was proposed to be remodelled as a paved surface for selective waste collection. Ultimately, by the institution's decision, the tree remained, and a paved surface from cobblestone on a course of permeable stone aggregate to let water through to the roots was designed between the tree and the fence (Fig. 7, 8, 9). Other examples of permeable surface systems should also be noted: openwork concrete pavers filled with divots or aggregate, crushed large-fraction aggregate, or plastic grass pavers (William, Hunt, 2006, p. 2-3). When the roots of a tree that is many years old do not have access to water and air under a layer of concrete, they search for these elements by developing the roots upwards, damaging the foundations of cellars and raising pavers above a pavement's surface (Zimmermann et al., 1981). A similar situation took place here, see Fig. 5, Fig. 6. 


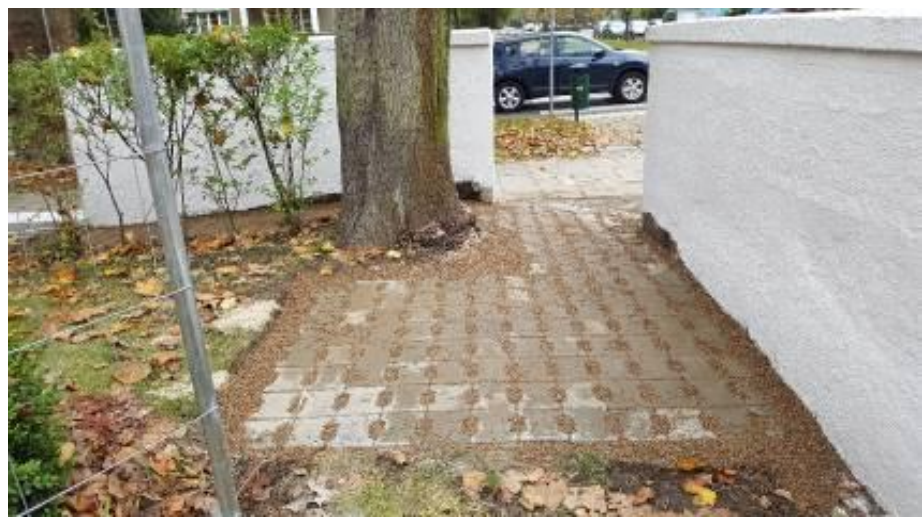

Fig. 9. Front garden at 21 Monte Cassino Street, view from the external side of the fence. The surface is water-permeable, without the use of cement. Source: author.

Ryc. 9. Przedogródek przy ul. Monte Cassino 21, widok od strony wewnętrznej ogrodzenia. Nawierzchnia jest przepuszczalna dla wody, bez użycia cementu. Źródło: autor.

As mentioned earlier, access to sunlight inside residential buildings is crucial. However, trees planted too close to buildings cause problems with fungi and lichens that damage roof and facade surfaces. Residents often complain about falling leaves which block gutters. Another problem associated with extensive tree crowns are animals such as martens, which can climb a tree and enter the roofing, where they damage the thermal insulation and waterproofing layer. In addition, the large number of leaves that fall during autumn, especially those with palmate-lobate and palmateundulate leaf blades, can become a problem on a small plot (Seneta, 1991).

Most of these problems can be avoided during the design and plant material selection stage and when we hire a landscape architect to work on the landscaping design of the area around a building. Otherwise, the cost of amending the situation will be very high. It entails, for instance, arborist services and work from a basket lift, which cannot guarantee that the problem will not reappear in the future.

\section{CASE II: HOUSING COMPLEX GREENERY - LESS AND LESS TREES, MORE AND MORE CONCRETE}

Between the 1960s and 1980s, many so-called panel block buildings were built in Poland, with green areas (mostly lawns) around them. Due to the growing amount of cars, a demand for parking spaces near the building appeared, and thus many square metres of previously green land were covered with concrete or pavers. The lack of cooperation with landscape architects and no horticultural knowledge about trees, which are being surrounded by concrete and pollarded, became clearly evident here.

Another example are unnaturally cut trees, subjected to so-called pollarding (Fig. 10), which are currently a frequent sight in cities.

Pollarding disrupts a tree's physiological balance and makes plants susceptible to infections and pests, which leads to a slow death, not to mention lowering the aesthetic value of the landscape. When ecological aspects are concerned, this mostly entails soil erosion and a disruption in water conditions (Borowski J., Motas M., 2014). In this specific case, that of the area at Stowackiego Street in Goleniów, the trees died within only a year's time!!! Figures 10 and 11 present, to the left, the state as seen in 2020, while the photos on the right show the present state.

The residents, in fear for their safety, commission companies that offer plant maintenance services to either cut or remove a tree. These are expensive services which employ heavy machinery in the form of a basket lift, chainsaws, branch grinders and containers for plant waste. Over a number of years, the number of cars equipped with basket lifts in Szczecin increased by several hundred percent. At present, they belong to around a dozen companies that offer basket lift services, which is a sign of high demand for pollarding and cutting the crowns of trees. 


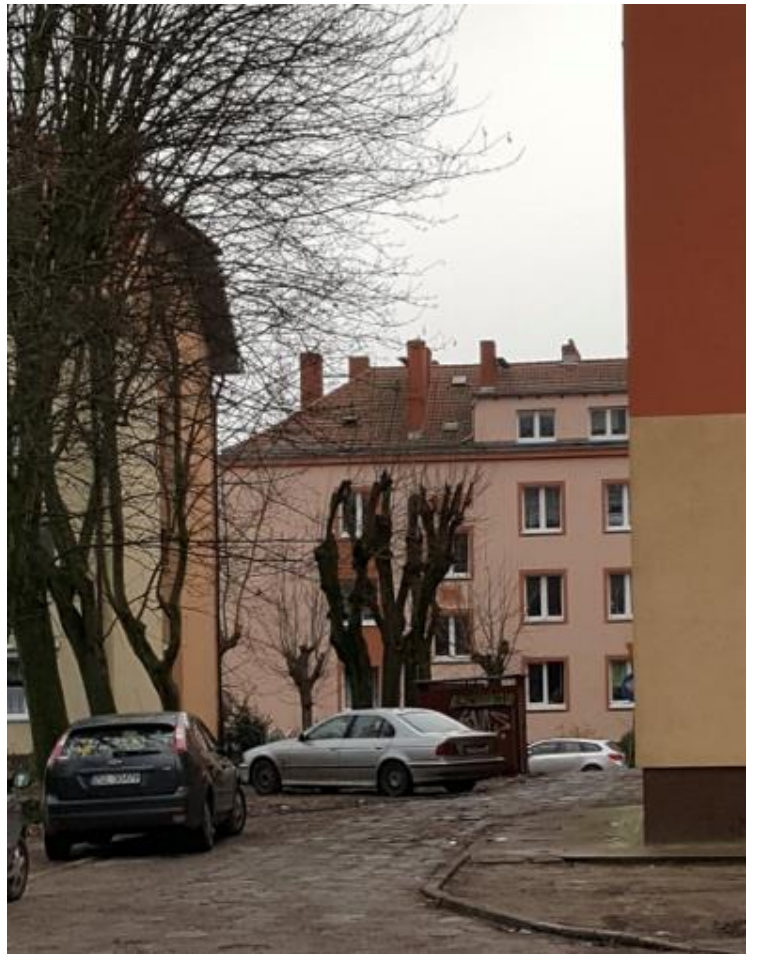

Fig. 10. Trees, housing complex greenery at Słowackiego Street in Goleniów. Photo made in September 2020. Source: author.

Ryc. 10. Drzewa, zieleń osiedlowa przy ul. Słowackiego w Goleniowie. Zdjęcie wykonane we wrześniu 2020 r. Źródło: autor.

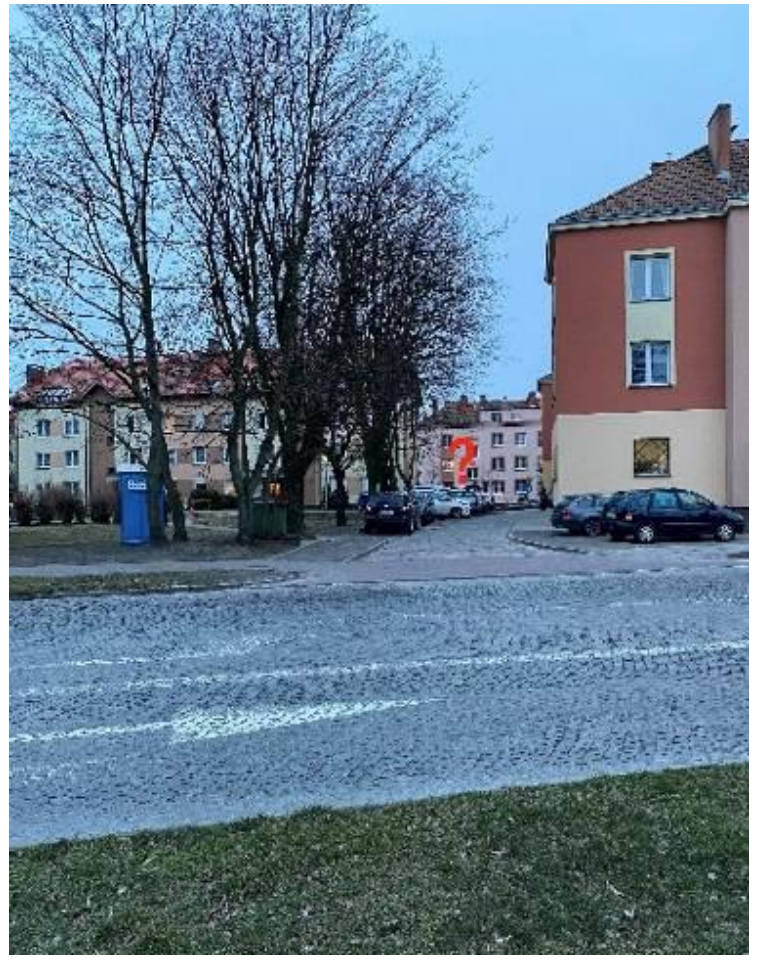

Fig. 11. A lack of pollarded trees, housing complex greenery at Słowackiego Street in Goleniów. Photo made a year later, in March 2021. Source: author

Ryc. 11. Brak ogłowionych drzew, zieleń osiedlowa przy ul. Słowackiego w Goleniowie. Zdjęcie wykonane rok później, w marcu 2021 r . Żródło: autor.

\section{CASE III: STREET GREENERY - MISTAKES ARE REPEATED}

The section on street greenery shall present cases from the city of Goleniów, where trees used to grow in difficult urban conditions. These conditions became significantly worse after the renovation of a pavement surfaces along the city's main arterial, namely Konstytucji 3 Maja Street. Older, preexisting trees had their trunks encircled by concrete pavers which blocked access to water, air and nutrients. Below is a photograph depicting the trees as seen in 2017 (Fig. 12).

Figure 13 depicts the same location in Goleniów and the same tree, with a view showing how the trees roots raised the concrete pavers in search of water and air over a period of 3.5 years.

Another photo (Fig. 14) from July 2017 shows the very difficult adaptation of a different tree to its new, worse conditions, caused by the pavement's renovation. In July 2017, the tree was observed to be in very poor condition. The deterioration of its appearance over a short period of time was visible in the form of a gradual reduction in its crown branching, with later seeping from inside the trunk and the symptoms of fungal diseases visible on its bark.

The photo below (Fig. 15, Fig. 16) shows the same place where the previous tree had been located. In March 2021, the old tree was cut down and replaced with a new, younger specimen. In Figure 15 , the new tree is marked in red. 

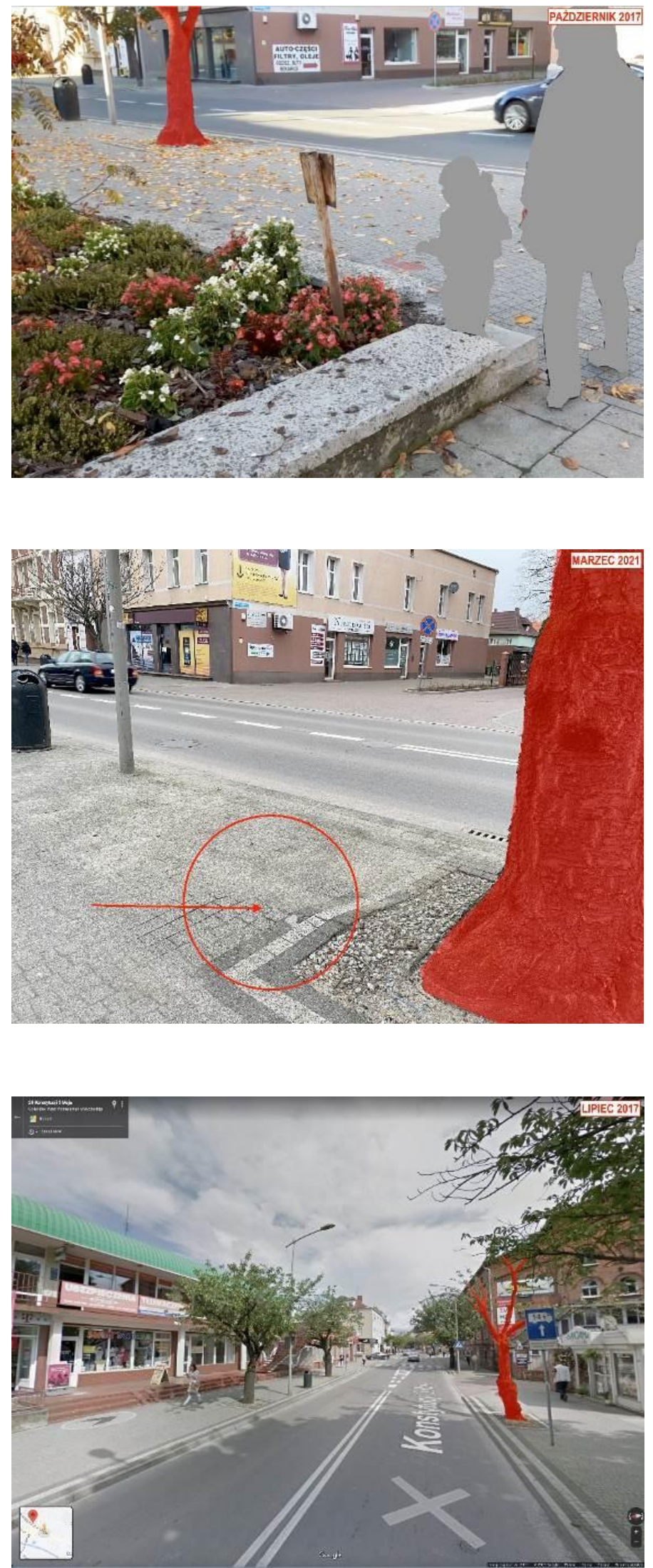

Fig. 12. Tree at Konstytucji 3 Maja Street in Goleniów after the placement of concrete pavers around the trunk. As seen in October 2017. Source: author.

Ryc. 12. Drzewo przy ulicy Konstytucji 3 Maja w Goleniowie po położeniu kostki betonowej wokół pnia. Stan na październik 2017. Źródło: autor.

Fig. 13. Tree at Konstytucji 3 Maja in Goleniów after the laying of concrete pavers around its trunk, same location, photo made 3.5 years later in March 2021. Source: author.

Ryc. 13. Drzewo przy ulicy Konstytucji 3 Maja w Goleniowie po położeniu kostki betonowej wokół pnia, to samo miejsce, zdjęcie wykonane 3,5 roku później - marzec 2021. Źródło: autor.

Fig. 14. A different tree at Konstytucji 3 Maja Street in Goleniów after the laying of concrete pavers around its trunk. As seen in July 2017. Source: Google maps, 2021.

Ryc. 14. Kolejne drzewo przy ulicy Konstytucji 3 Maja w Goleniowie po położeniu kostki betonowej wokół pnia. Stan na lipiec 2017. Źródło: Google maps, 2021. 


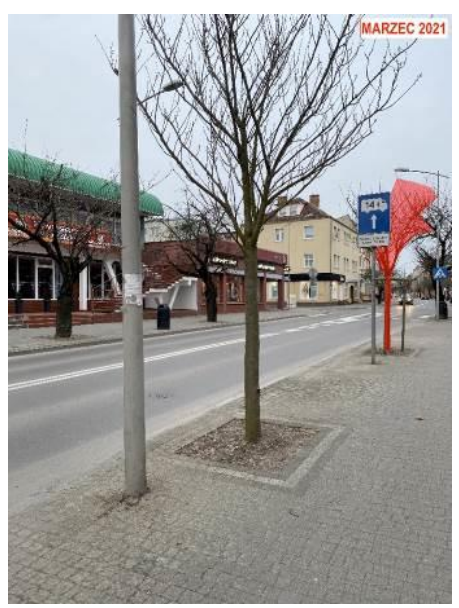

Fig. 15. Tree along Konstytucji 3 Maja Street in Goleniów with concrete pavers around its trunk. As seen in March 2021, after the replacement of the old tree. Source: author.

Ryc. 15. Drzewo przy ulicy Konstytucji 3 Maja w Goleniowie z kostką betonową wokół pnia. Stan marzec 2021, po wymianie na nowe drzewo. Źródło: fot. autor.

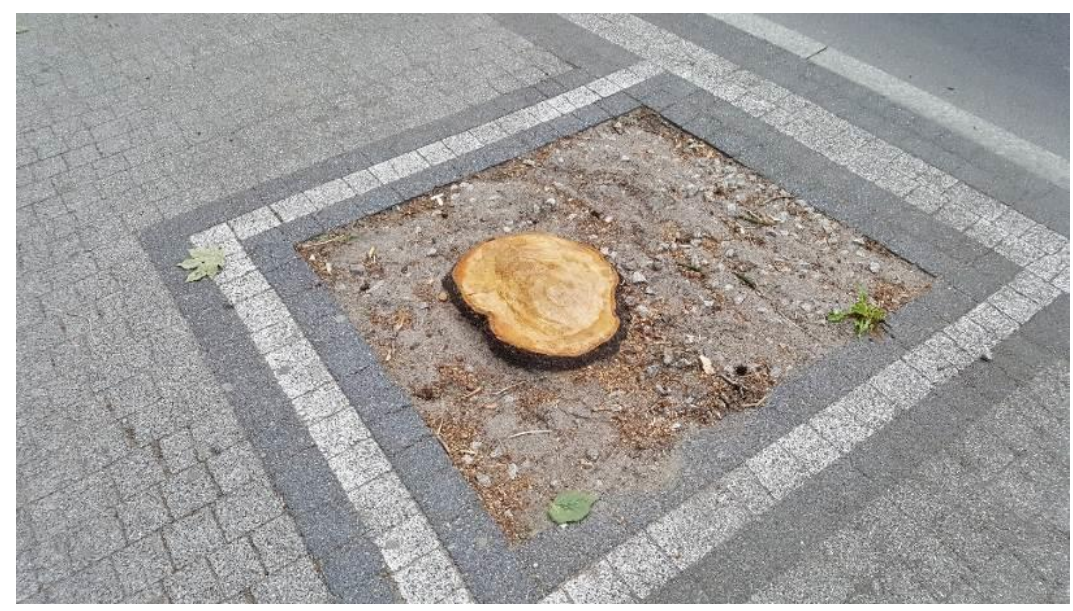

Fig. 16. The site of the tree immediately after its removal, at Konstytucji 3 Maja Street in Goleniów. As seen in September 2018. Source: author.

Ryc. 16. Drzewo zaraz po ścięciu, przy ulicy Konstytucji 3 Maja w Goleniowie. Stan na wrzesień 2018 roku. Źródło: fot. autor.

\section{METHODS OF REPLANTING NEWLY PLANTED TREES AND MONUMENTAL TREES}

Only specialist plant (tree) nurseries perform so-called plant material nursing procedures, including root trimming (Sobczak, 1999). 'Nursing is the replanting of plants during production, intended to induce them to develop a compact root system, which ensures favourable plant accommodation conditions after planting at a permanent location. Plants should be nursed in a spacing that is suitable to their species and variation. After the commencement of nursing, bushes and trees grow in the same container for 1-2 years, and later in the ground for 2-4 years' (ZSZP, 2018). After relocating a tree to a permanent planting location, it must be stabilised using wooden posts and watered. The stabilisation using posts must remain in place for 2 years (Bartosiewicz A., 1977).

Another factor that affects the chance of a plant accepting its new location is the depth at which its roots are placed (Fig. 17). The depth of a ditch for planting a tree should correspond to the height of the root mass. The tree should be placed at the same and sometimes even at a higher level than it previously grew at, so that the root collar is not covered by the soil. The root area must have access to air, as this ensures the tree will be in good health (Zimmermann A., 2009, p. 369-375). However, we should also remember that excessive moisture, especially in the case of clayey soils, also prevents air from reaching the roots (Fig. 18). When we cover a tree with too thick of a soil or litter layer, it will begin to suffocate and produce roots that surround the trunk (Ellen A., 2000). Every tree, irrespective of size, can be replanted. In the case of environmentally valuable trees that have extensive root systems, it is necessary to clean the roots from the soil, performed by highpressure air spraying, and prepare them for transport. Procedures within the area of tree root systems are performed using an AirSpade device.

Trees with a height of up to $6 \mathrm{~m}$, nursed for years in a tree nursery, have a root mass with a volume of $1 \mathrm{~m}^{3}$ and weigh more than a ton. This is why a tree with a root system regenerated in a mass has a volume that can be transported. This not only limits possible root system damage but also lowers the tree's weight, which aids in moving and planting. Both of these systems have their ad- 
vantages and disadvantages. The system of cleaning roots with pressurised air is more universal (Fig. 19, Fig. 20). It can be used to replant even large trees in difficult-to-access spots. However, the planning of new plantings in an urban setting and plant material selection should be performed in cooperation with specialist tree nurseries with many years of experience.

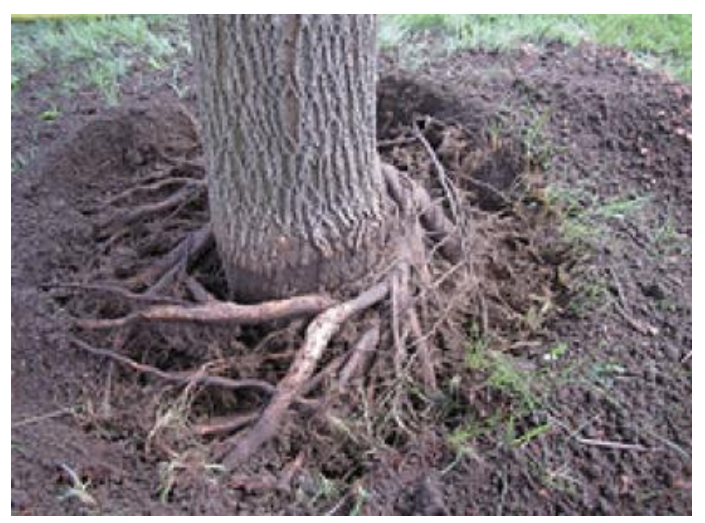

Fig. 17. A tree planted too deep into the ground. Source: LMC 2017

Ryc. 17. Drzewo zbyt głęboko posadzone. Źródło: LMC 2017

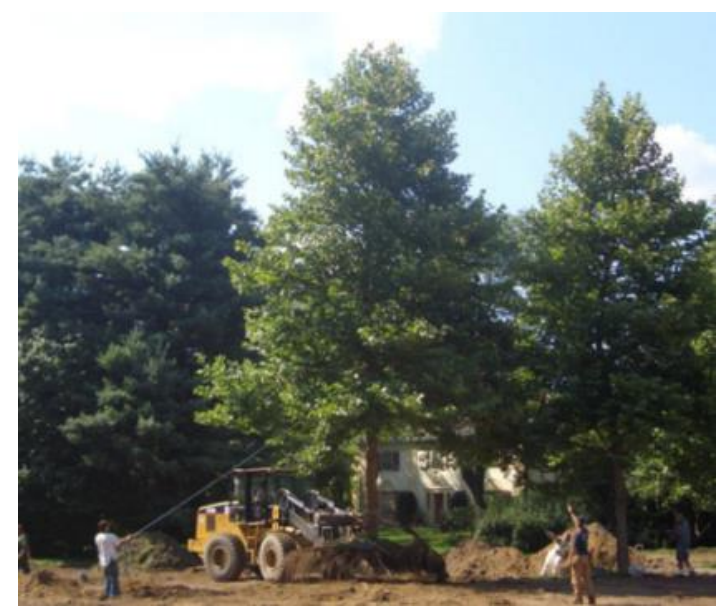

Fig. 19. Tree relocated with its entire, pre-cleaned root system. Source: Taking

Ryc. 19. Drzewo przenoszone z całym oczyszczonym systemem korzeniowym. Żródło: Taking

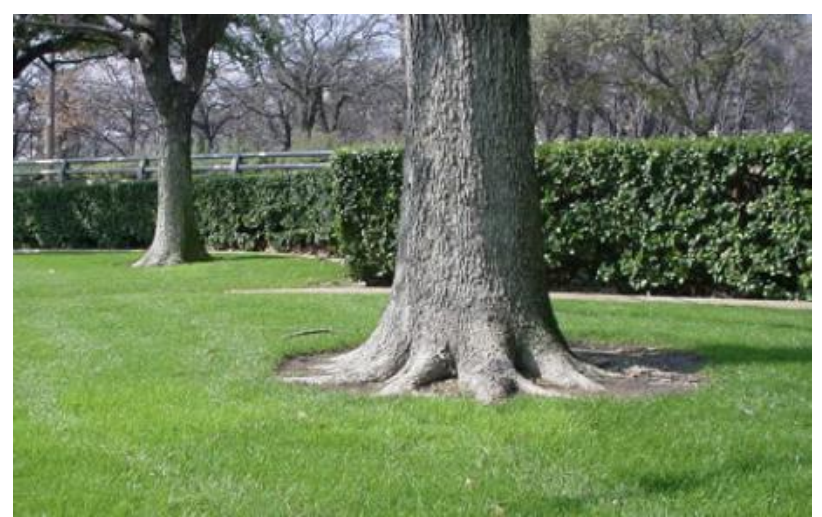

Fig. 18. A tree with a healthy transition between the trunk and the roots. Source: Ken Salwail 2017

Ryc. 18. Drzewo ze zdrowym przejściem między pniem a korzeniami. Źródło: Ken Salwail 2017

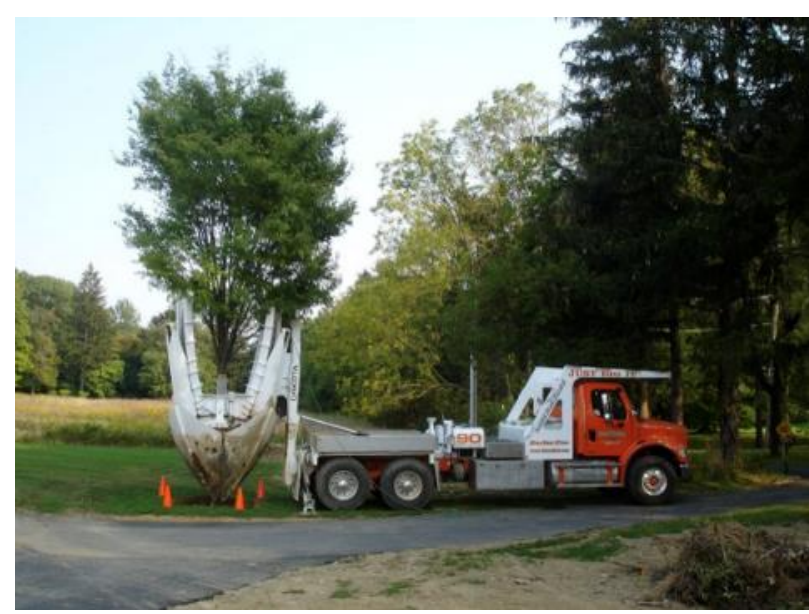

Fig. 20. Tree relocated with a tree transplantation machine. Source: Benckini R. 2017

Ryc. 20. Drzewo przenoszone za pomocą przesadzarki. Źródło: Benckini R. 2017

It also appears beneficial for municipal authorities, in conjunction with a municipal gardener, to enact a city greenery management system, which could include a record of all valuable tree specimens. Such a system, based on GIS technology, could include information about a tree's age and health and the scope and times of maintenance work. Record keeping and constant control over significant municipal greenery assets can also enable precise and professional tree care. Now York already has a street tree records system. It is the most precise and detailed map of city trees in the world. 


\section{POSITIVE EXAMPLES OF PLANTING TALL TREES IN URBAN SPACE}

The trees and bushes presented on the photo below have sufficient space around them and thus possess suitable conditions for development and growth.

The trees located alongside the strip of greenery near a Szczecin shopping centre (Fig. 21) were found to be in very good health. Apart from the factor of having ample space around the trunk, there was also an observable, minimal incline and the lowering of the surface of the lawn in the direction of plants. The incline of the ground makes it so after every instance of rain, water is transported directly towards the plants. The trees were observed to be growing increasingly larger each year. Apart from the incline and ample space around the plants, barriers were installed to prevent the mechanical compaction of the soil around the plants by treading on it. Another case is Bolesława Krzywoustego Street in Szczecin, along which there is a strip of greenery. The appearance of the trees that grow there was found to be a sign of correct species selection and choice of planting the greenery in the form of a strip. The trees along Bolesława Krzywoustego Street grew in metal grates, but were also planted in the vicinity of bushes, where their roots had suitable access to water and air (Fig. 22).
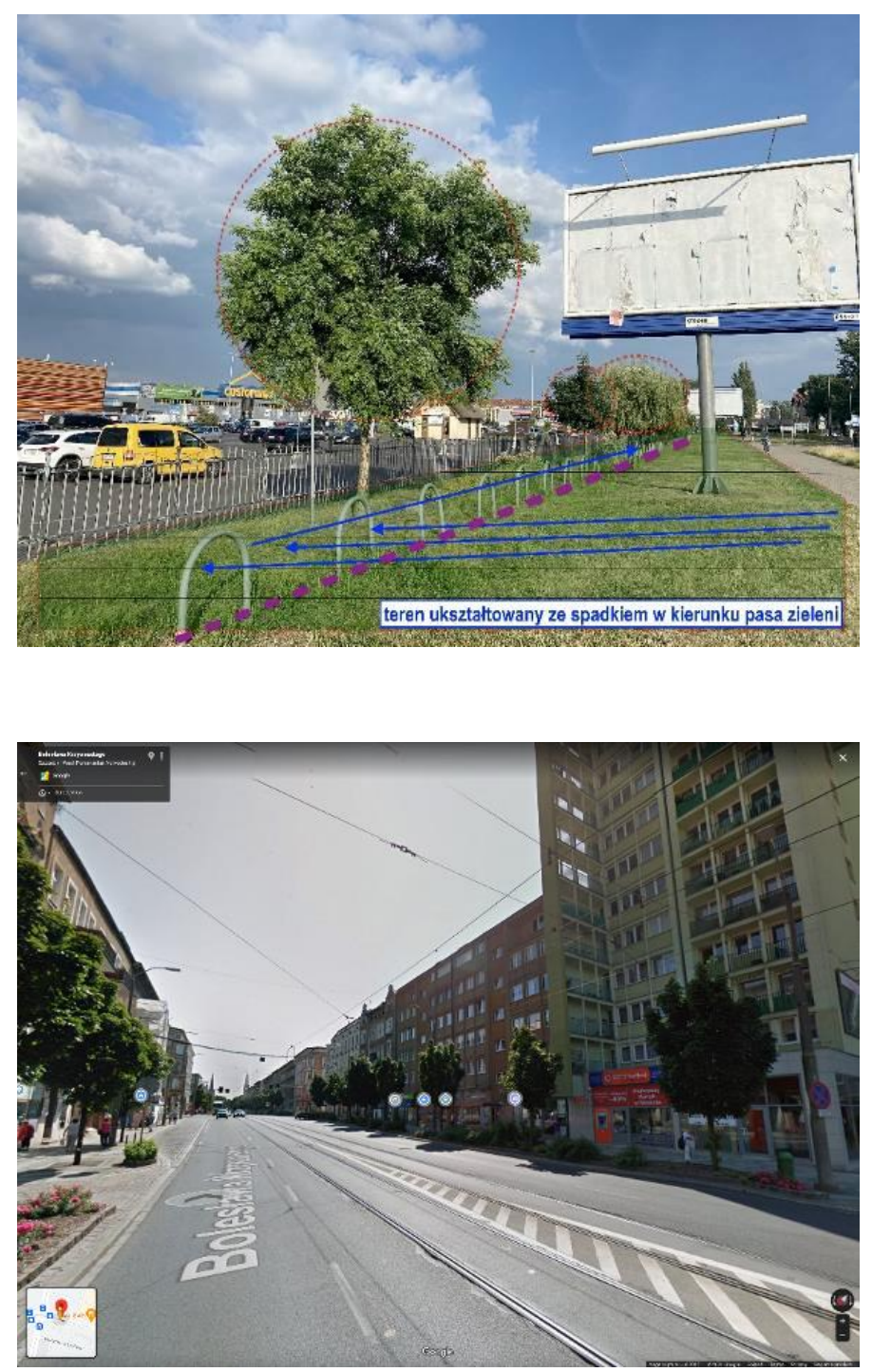

Fig. 21. Green strip near a shopping centre in Szczecin. Source: Pfot. author.

Ryc. 21. Pas zieleni przy centrum handlowym w Szczecinie. Żródło: fot. autor.
Fig. 22. Strip of greenery along Bolesława Krzywoustego Street in Szczecin. Source: Google maps, 2021.

Ryc. 22. Pas zieleni przy ulicy Bolesława Krzywoustego w Szczecinie. Żródło: Google maps, 2021. 
In the lower right-hand corner of an archival photograph from 1908 (Fig. 23), which shows a view of Konstytucji 3 Maja Street in Goleniów, one can see trees. In this period, trees were given suitable conditions for proper growth. The pedestrian path visible bordered on a demarcated strip of tall greenery.

Below is a photograph and a plan view of Konstytucji 3 Maja Street, which show that the distance from the centreline of the carriageway to the building line is around $8.5 \mathrm{~m}$ (Fig. 24, Fig. 25). This shows that the width of the existing pedestrian path still allows for the introduction of the trees that had existed, along with a strip of greenery, into the street's remodelling design.

Fig. 23. 1908, District Court building at Konstytucji 3 Maja Street in Goleniów. Source: FOTOPOLSKA, 2021.

Ryc. 23. Rok 1908 , Sąd Rejonowy przy ulicy Konstytucji 3 Maja w Goleniowie. Żródło: FOTOPOLSKA, 2021.

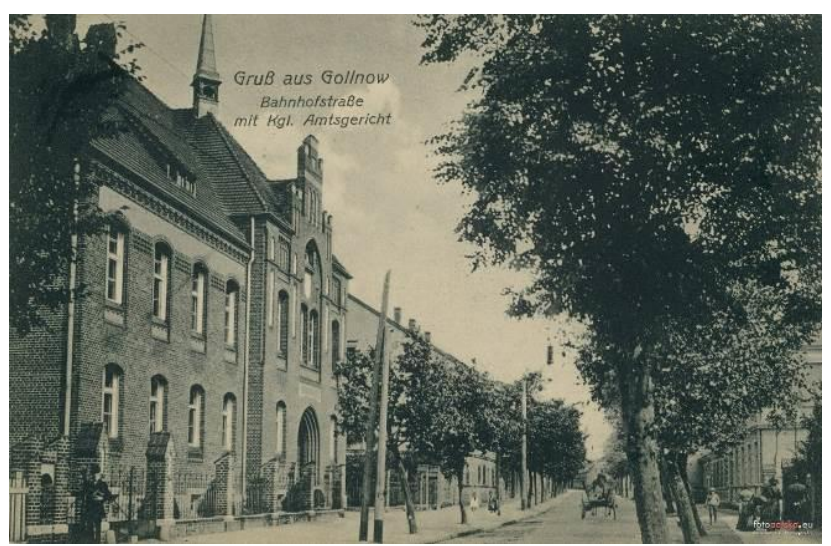

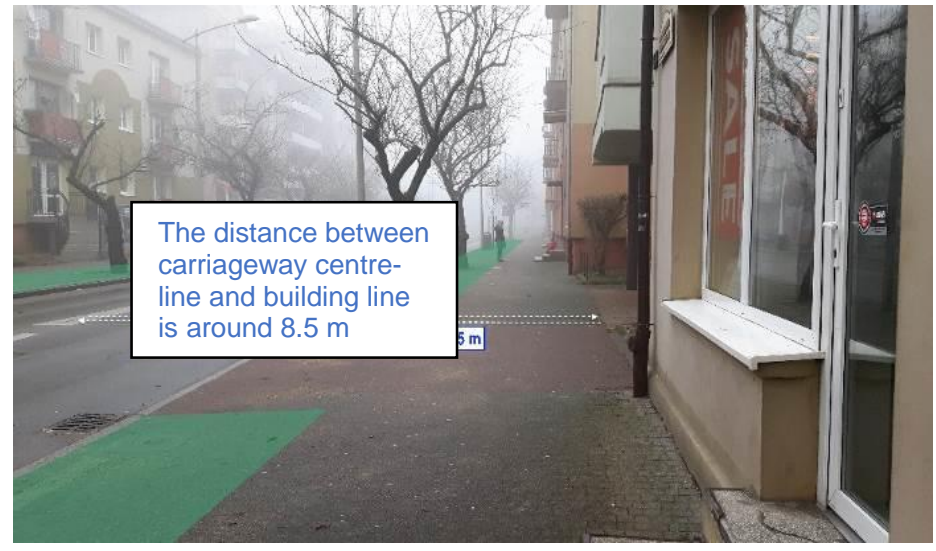

Fig. 24. View of Konstytucji 3 Maja Street in Goleniów. Source: photo by author

Ryc. 24. Widok na ulicę Konstytucji 3 Maja w Goleniowie. Źródło: fot. autor

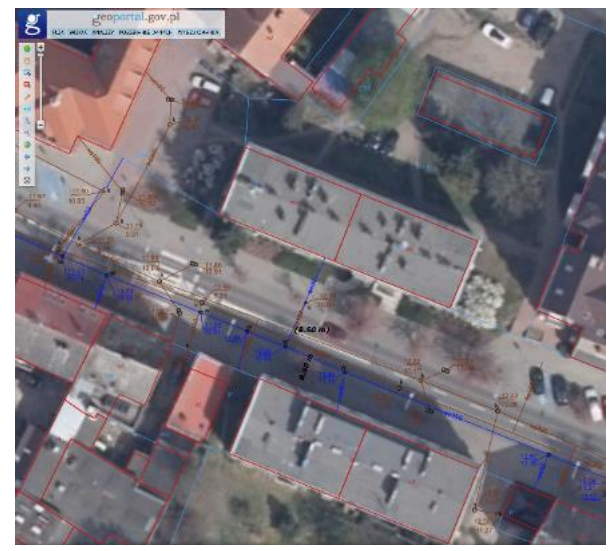

Fig. 25. Plan view of Konstytucji 3 Maja Street in Goleniów. Source:

www.mapy.geoportal.gov.pl.

Ryc. 25. Widok z góry na ulicę Konstytucji 3 Maja w Goleniowie. Źródło: www.mapy.geoportal.gov.pl

\section{CONCLUSIONS}

Based on the research and analyses performed, it is possible to formulate conclusions that can contribute to improving the current and often unfavourable situation of tall trees in urban space.

1. For a considerable amount of time, a continuous reduction of space around trees has been in effect. Some tree species need space, especially when in natural conditions they form wide and picturesque crowns. 
2. Proper tree species and variation selection is necessary in cities.

3. It is always key to find the essence of the problem, while asking as many questions as possible, and finding answers. Why is the tree not growing? We should make attempts to understand the problem in all of its complexity, as there is never only a single factor that determines whether a tree shall grow and develop in a healthy manner.

4. Providing trees with minimal, favourable development conditions does not need to entail a very high cost and the application of the latest construction technology. Smart solutions to problems often involve simple means applied at the correct moment, during the planning process. For instance: levelling the terrain and arranging surface runoff flow direction, planting plants in larger groups, refraining from reducing absorptive surfaces around the roots of older, especially monumental trees, or the planting of trees with greater trunk diameters.

5. Treating the clear and equal division into a carriageway, green strip and pedestrian walkway in a circulation path needs to be treated as necessary.

6. Due to the dynamic development of cities, road infrastructure, recreational spaces, and the necessity to preserve the landscape, newly drafted local spatial development plans require close cooperation between architects, landscape architects, gardeners and specialists from many other fields.

7. A lack of trees and extensive paved surfaces (often concrete squares) are clearly perceived as negative by humans on hot days and other periods. Tall greenery provides numerous benefits, including shade, biodiversity, a pleasant microclimate, it protects against pollution in the form of particulate matter, smoke, etc.

8. During the execution of new projects or the modernisation of existing urban spaces that assume the introduction of several dozen percent of paved surfaces (concrete surfaces), the comfort of living in urban spaces deteriorates significantly. Trees contribute to improving the attractiveness and quality of life within a city, which is why preserving and protecting trees in urban space should be a priority.

9. Trees are also a key part of our cultural and natural landscape, and it is also for this reason that they should be placed under protection within the landscape of cities, rural areas and open spaces.

\section{SUMMARY}

Problematic situations, future clashes between the development structure as 'urban tissue', via changes in the functio-spatial structure, and urban green space, can be controlled during the design stage. This shapes urban green areas. The proper selection of material, and not only of the structural, but also the plant type, in the hands of a good designer will surely foster an increase in the attractiveness of urban space for future generations. In cities, cases where specialists who practice procedures associated with the protection and development of green areas are not involved in the design and construction process are multiplying, and the poor consequences of this become apparent. This is often associated with insufficient knowledge instead of an insufficient budget. 


\section{OGRANICZONA PRZESTRZEŃ DLA DRZEW W ZAGOSPODAROWANIU URBANISTYCZNYM MIASTA (NA PRZYKŁADZIE WYBRANYCH LOKALIZACJI W SZCZECINIE I GOLENIOWIE)}

\section{WSTĘP}

Ograniczenia w utrzymaniu i nasadzeniach zieleni występują zarówno w dużych, jak i średnich miastach. Jest wiele przyczyn powstawania takiego stanu, ale ten zespół czynników, wywołujący określony negatywny skutek, można zminimalizować lub usunąć. Trzeba szukać rozwiązań. Jest wiele dowodów na to, że drzewa poprawiają warunki życia ludzi w mieście. Świadczy o tym niezliczona ilość napisanych książek i artykułów. Obecnie występuje potrzeba badania przyczyn małej ilości zieleni. Dlaczego jej w większości aglomeracji miejskich nie przybywa, a nawet w wielu miejscach ubywa bezpowrotnie. Wydaje się, bo powszechnie przyjęła się opinia, że drzewa nie będą okazale rozrośnięte w warunkach miejskich, z powodu zanieczyszczenia powietrza, pyłów, zasolenia i innych. Jednak, na co wskazują badania porównawcze, często w mniejszych miastach lub miejscach oddalonych od ścisłego centrum, zieleń jest w gorszej kondycji zdrowotnej, niż ta zlokalizowana przy głównych arteriach komunikacyjnych. Dlaczego, tak się dzieje? Co można zrobić, żeby to zmienić?

\section{STAN BADAŃ - DRZEWA W KRAJOBRAZIE MIAST NA ŚWIECIE}

W 2009 roku podczas 10th National Street Tree Symposium w Australii, drzewa postrzegano jako dostarczające miastu wielu korzyści środowiskowych, a zwłaszcza cienia (Ely, 2009, p. 87-98). Oprócz tego zwrócono uwagę, że mieszkańcy bardzo cenią sobie korzyści wizualne drzew. Natomiast, przeciwstawny jest szereg problemów wynikających z kolizji drzew z infrastrukturą miejską itp. Miasto często tłumaczy się z mniejszej ilości sadzonych drzew, na przykład chęcią skoncentrowania się i efektywniejszego zarządzania, poprzez mniejszą ilość zieleni do pielęgnacji. Często skarżą się na brak miejsca i ograniczenia wynikające z braku wody oraz zabudowywanie pozostającej jeszcze wolnej przestrzeni w mieście. Wyjściem z trudnej sytuacji braku wody, jest kierowanie wód opadowych w kierunku obszaru zieleni. Ważne jest kombinacja dwóch czynników: zasobów zieleni z wykorzystaniem dostępnej wiedzy. Ely podaje we wnioskach, że potrzebne jest spójne podejście do organizacji przestrzeni z planem, we współpracy kilku branż, aby w przyszłości zapobiec sytuacjom, gdzie zieleń staje się najmniej ważna

Z kolei, Ferrini i inni zwracają uwagę na aspekt łagodzenia zmian klimatycznych przez drzewa (Ferrini i in. 2014. p. 243). Przy sadzeniu drzew, należy wziąć pod uwagę bardzo ważne trzy czynniki, czyli zapewnić umieszczenie odpowiedniej rośliny w określonym miejscu, w określonym czasie i przy użyciu odpowiednich technik. Ogólnie rzecz biorąc, czynniki te, na które jednak w pewnym stopniu wpływają zmiany klimatyczne, dzielą się na trzy główne kategorie: projektowanie, lokalizacja i kwestie związane z późniejszym utrzymaniem zieleni. Czynniki, które należy wziąć pod uwagę przy doborze drzew przy ulicach lub w parkach, to wymagania gatunku i reakcja na przycinanie, pokrój drzew, odporność na choroby, szkodniki owadzie, adaptację gleby, tolerancję na cień lub słońce, pochodzenie i odmiany drzew

Inżynier budownictwa Paul Crabtree, tak przedstawia projekt modernizacji ulicy dla Van Buren Street w Phoenix (Crabtree P. 2020, p.9) - patrz ryc. 1.

Drzewa są integralną częścią projektu urbanistycznego każdego miasta. Drzewa miejskie w parkach, na dziedzińcach, ulicach i na działkach stanowią od wieków element urbanistyki i architektury krajobrazu (Arnold, 1980). Autor książki „Trees in Urban Design” zachęca architektów krajobrazu i urbanistów do wykorzystywania drzew nie jako dekoracji, ale jako żywych materiałów do budowania i wzmacniania przestrzeni miejskich. Podkreśla się również, ze proces urbanizacji ma tendencję wzrostową (Lüttge, Buckeridge, 2020, p. 1), a związki między zieloną przestrzenią, a zdrowiem psychicznym człowieka są znaczące (Beyer K. i in. 2014). 


\section{STAN AKTUALNY (SZCZECIN I GOLENIÓW)}

W latach 1806-1813 w okresie okupacji francuskiej Szczecin otrzymał charakterystyczny układ przestrzenny czytelny w tkance miasta do dzisiaj. Stanowią go koliste place i promieniście odchodzące od nich ulice wraz z wyraźnie wydzieloną przestrzenią dla drzew. Tak zaprojektowany układ zapewniał zieleni odpowiednią strefę potrzebną do rozwoju i zachowania zdrowotności. Po roku 1960 powstało w centrum miasta wiele budynków z tzw. „wielkiej płyty”, a wokół nich tereny zieleni (głównie trawiastej). W ostatnich latach pojawiło się duże zapotrzebowanie na miejsca parkingowe, czego konsekwencją jest masowa redukcja terenów zieleni i wprowadzanie w to miejsce coraz większych powierzchni utwardzonych. Podobną sytuację obserwuje się w wielu miastach, również tych mniejszych, jak na przykład Goleniów (województwo zachodniopomorskie). Kierunek biegu tych działań, ogranicza w znaczący sposób możliwości swobodnego rozwoju istniejących nasadzeń i nie zwiastuje nic dobrego na przyszłość. Należy podjąć pilne zabiegi mające na celu poprawę sytuacji powodującej zamieranie i usuwanie okazałych kilkudziesięcioletnich drzew z przestrzeni miejskiej.

Szczecin jest określany jako „miasto zieleni”, o czym świadczy częste powtarzanie tego stwierdzenia przez jego mieszkańców. W prezentowanym mieście jest obecnie 16 parków, 93 zieleńce i prawie 5 tysięcy metrów kwadratowych kwietników (ZUK, 2021). Najbardziej znanym i lubianym przez mieszkańców i turystów miejscem zielonym jest Park Kasprowicza. Na wyróżnienie zasługuje również plac Jasne Błonia, gdzie wzdłuż ulic Szymanowskiego i Ogińskiego posadzono licznie platany klonolistne (pomniki przyrody) tworzące piękne podwójne aleje (Ryc. 2). Kolejnym zielonym miejscem są powstałe na przełomie XIX i XX wieku Wały Chrobrego z dębami rosnącymi wzdłuż ulic Zygmunta Starego i Szczerbcowej. W sąsiedztwie Wałów Chrobrego znajduje się Park Żeromskiego. Natomiast największy park leśny znajdujący się w granicach miasta to Park Leśny Arkoński. Jak podaje Czekiel-Świtalska: "W Szczecinie na jednego mieszkańca przypada 64,7 $\mathrm{m}^{2}$ zieleni wypoczynkowej, dla porównania Warszawa ma 47,2 $\mathrm{m}^{2}$, natomiast Kraków 35,8 $\mathrm{m}^{2}$ " (CzekielŚwitalska, 2010, p. 165-182).

Z kolei w Goleniowie, można zauważyć, że miasto ma wiele parków, które są dawnymi cmentarzami. Największy park miejski to Park 750-lecia (aktualna nazwa Park XXX-lecia Polski Ludowej), który jest dawnym niemieckim i żydowskim cmentarzem. Kolejno można wymieniać: Park - były cmentarz ewangelicki przy kościele św. Jerzego, Park - były cmentarz ewangelicki, ul. Wojska Polskiego (Polińska, Gaj, 2016), Park im. Paderewskiego przy Nadleśnictwie Goleniów, ul. Parkowa.

\section{PRZEDMIOT BADAŃ}

Przedmiot badań stanowią zlokalizowane na terenie miast Szczecina i Goleniowa obiekty zieleni miejskiej, obejmujące kategorie takie jak: przedogródki miejskie, zieleń osiedlowa oraz zieleń uliczna. Przykłady obiektów, który poddano obserwacjom i analizom to: przedogródek przy ul. Monte Cassino 21 w Szczecinie, drzewa na terenie Wspólnoty Mieszkaniowej przy ul. Słowackiego w Goleniowie oraz drzewa przy ul. Konstytucji 3 Maja w Goleniowie. Wybrane obszary zieleni miejskiej badano w okresie od lipca 2017 roku do marca 2021 roku. Dla porównania przywołano istniejące już pas zieleni wzdłuż głównej arterii komunikacyjnej w Szczecinie, czyli ul. Bolesława Krzywoustego i pas zieleni przy centrum handlowym w Szczecinie.

\section{CEL BADAŃ I METODYKA BADAŃ}

Celem pracy jest ocena stanu istniejącego wybranych obiektów zieleni pod względem funkcji zieleni jakie powinny spełniać w mieście, a w szczególności stanu zachowania istniejących drzew. Badania skupiły się nad rozpoznaniem, czy są przestrzegane standardy utrzymania i ochrony drzew w mieście, i jakie są konsekwencje nie wdrożenia tych standardów. Artykuł ma na celu przedstawić bardzo ważny problem zamierania drzew w centrum miast, w dosłownym tego słowa znaczeniu. Wskazano również rozwiązania problemu trudnej sytuacji drzew w mieście. W pracy zastosowano badania i obserwacje terenowe oraz metodę porównawczą poszczególnych przypadków, dotyczą- 
cych wyżej wymienionych obiektów zieleni, sporządzone na przestrzeni czasu tj. w latach 20172021.

\section{ANALIZA PRZEPISÓW I USTAW ZWIAZANYCH Z OCHRONA DRZEW W MIEŚCIE NA PRZYKŁADZIE SZCZECINA}

Obecnie (2021 r.) zezwolenie na wycinkę jest wymagane dla drzew, których obwód pnia mierzony na wysokości $5 \mathrm{~cm}$ przekracza: $80 \mathrm{~cm}$ - w przypadku topoli, wierzb, klonu jesionolistnego oraz klonu srebrzystego; $65 \mathrm{~cm}$ - w przypadku kasztanowca zwyczajnego, robinii akacjowej oraz platana klonolistnego; $50 \mathrm{~cm}$ - w przypadku pozostałych gatunków drzew. Ustawa o ochronie przyrody reguluje, iż udzielenie zezwolenia na usunięcie drzew i krzewów o obwodach powyżej przyjętych w ustawie, uzależnia się od wykonania nasadzeń zastępczych, tym samym odroczenia terminu uiszczenia opłaty, na okres trzech lat od dnia upływu terminu wskazanego w zezwoleniu do wykonania nasadzeń zastępczych. Urzędnicy sugerują ilość nasadzeń, termin, gatunki nasadzeń i obwód w cm pnia drzewa (Ustawa o ochronie przyrody). Dodatkowymi wymogami są określone cechy materiału roślinnego, który powinien być zdrowy, posiadać prosty pień (zazwyczaj jest to obwód minimum 14-16 cm, przy pomiarze na wysokości $100 \mathrm{~cm}$ ). To jest w przypadku drzew, natomiast sadzonki krzewów muszą być 2-3 letnie z przynajmniej 5-7 dobrze wykształconymi pędami głównymi z typowymi dla odmiany rozgałęzieniami.

Organ właściwy do wydania zezwolenia zobowiązuje wnioskodawcę do złożenia oświadczenia $z$ planem zieleni ( $w$ formie papierowej), o wykonaniu nasadzeń zastępczych w ciagu 14 dni od ich wykonania. Zgodnie z przepisami, dalsza opieka nad posadzonymi drzewami i krzewami należy do wnioskodawcy i trwa przez okres 3 lat.

W związku z powyższymi przepisami, ujawniła się konieczność zmian w administrowaniu zielenią miasta Szczecina, czyli sadzenie nowych drzew, według ogólnie przygotowanego planu nasadzeń i późniejszego planu pielęgnacji. Dlatego też, w Szczecinie w ostatnim czasie zostało wprowadzone Zarządzenie Prezydenta Miasta Szczecin. Zarządzenie jest w sprawie Standardów utrzymania, ochrony i rozwoju terenów zieleni Miasta Szczecin oraz obowiązków służących ich wdrożeniu. Porównując sytuację w innych polskich miastach, przykładowo w Warszawie i Wrocławiu, podobne zarządzenia zostały podpisane już w 2016 roku. Dlaczego w Szczecinie nastąpiło to tak późno?

\section{PRZYKŁAD I. PRZEDOGRÓDEK MIEJSKI - ISTOTA PROBLEMU ZOSTALA ROZPOZNANA}

W Strategii Rozwoju Szczecina 2025 (Strategia Rozwoju Szczecina 2025, 2011) realizowanej przez prezydenta, jedno $z$ haseł to Zielone Miasto, gdzie w planach jest połączenie i dbałość o trzy główne obszary: powietrze, wodę i przyrodę. W ramach realizowanego przez Miasto Szczecin programu PLATAN w Szczecinie w latach 2018-2019 przybyło kilkanaście tysięcy drzew i krzewów. Natomiast biorąc pod uwagę ilość wycinek drzew, jaka nastąpiła w roku 2017 po zliberalizowaniu przepisów w Ustawie o ochronie przyrody, odsłania to problem, który właściciele prywatnych posesji mają z dużymi drzewami. Drzewami, które siłą wzrostu, docelową wysokością, czy też szerokością koron są zupełnie nieprzystosowane do specyfiki siedliska, w którym rosną. Niewiedza o tym, że sadzenie gatunków drzew tworzących szerokie korony w ciasnych przestrzeniach miasta, co jest widoczne dopiero po kilkunastu latach, kończy się decyzją o wycince. Drzewa o malowniczych, szerokich koronach, powinny mieć dużo miejsca do rozrostu i tylko wówczas dożyją kilkuset lat Bugała, 2000). Natomiast starsze okazy drzew, które już rosną od kilkudziesięciu lat, mają ograniczoną przestrzeń do rozwoju korzeni, co wynika z ubicia gleby wokół drzewa i tym samym braku dostępu powietrza i wody (Bugała i in. 1984). Zdjęcia poniżej przedstawiają widok na kolizję, jaka powstała pomiędzy starodrzewem, a historycznym ogrodzeniem przy ul. Monte Cassino w Szczecinie (Ryc. 5, Ryc. 6)

W przypadku ul. Monte Cassino w Szczecinie, problemem były dwa duże klony zwyczajne posadzone zbyt blisko linii starego ogrodzenia. Z wypowiedzi mieszkańców wspólnoty wynikało, że drzewa dają zbyt dużo cienia, zrzucając jesienią tony pięcio-klapowanych liści, a korzenie niszczyły 
nawierzchnię chodnika i stare ogrodzenie. Mieszkańcy wnioskowali do Wydziału Ochrony Środowiska Urzędu Marszałkowskiego Województwa Zachodniopomorskiego przy ul. Starzyńskiego, o usunięcie drzew. W drodze postępowania administracyjnego, decyzją urzędu uzyskano pozwolenie na wycinkę jednego z drzew. Był to klon, który najbardziej zacieniał i blokował dostęp światła do pomieszczeń mieszkalnych. Poza tym niszczył chodnik, a pień był uszkodzony przez piorun, co stanowiło zagrożenie bezpieczeństwa. Wydana decyzja na wycinkę określała też liczbę nasadzeń zastępczych, których gatunek i odmiana, oraz obwód pnia były ściśle określone w projekcie nasadzeń roślinnych. Decyzja o usunięciu drzewa została wykona, a stare ogrodzenie odnowione. W projekcie wzięto pod uwagę docelową wysokość proponowanych gatunków drzew, aby w przyszłości nie zdominowały przestrzeni przedogródka. Klon zwyczajny, jako drugie drzewo zgłoszone we wniosku o wycinkę, zlokalizowane było w rogu ogrodzenia, nie zacieniało okien budynku, ale niszczyło rozrastającym się systemem korzeniowym fundamenty starego muru ogrodzeniowego. Oprócz wniosku o wycinkę dwóch drzew mieszkańcy wykazali się również chęcią do wzięcia udziału w programie Zielone Przedogródki Szczecina. „Celem PROGRAMU jest polepszenie wizerunku Miasta Szczecin poprzez poprawę warunków i estetyki otoczenia budynków z uwzględnieniem renowacji już istniejących terenów zielonych - PRZEDOGRÓDKÓW' (ZBILK, 2017). We wniosku, projektowano w miejscu drugiego drzewa, wykonanie placu na selektywną zbiórkę odpadów. Ostatecznie, decyzją urzędu drzewo pozostało, a pomiędzy drzewem i murem ogrodzenia wykonano plac z kostki brukowej na kruszywach kamiennych, które przepuszczają wodę w głąb do korzeni (Ryc. 7, 8, 9). Warto wskazać również inne przykłady systemów nawierzchni przepuszczalnych: kostka betonowa ażurowa wypełniona darnią lub żwirem, duża frakcja kruszywa łamanego, plastikowa kratka trawnikowa (William, Hunt, 2006. p. 2-3). Gdy korzenie wieloletniego drzewa nie mają dostępu do wody i powietrza pod warstwą betonu, zaczynają szukać tych składników podnosząc wyżej korzenie, które niszczą fundamenty piwnic i unoszą płytki chodnikowe wyżej ponad poziom chodnika. (Zimmermann i in. 1981). Podobna sytuacja ma miejsce, patrz Ryc. 5, Ryc. 6.

Jak już wspomniano wcześniej, dostęp do światła słonecznego we wnętrzach budynków mieszkalnych jest bardzo ważny. Natomiast drzewa posadzone w zbyt bliskim sąsiedztwie budynków powodują też problemy z grzybami i porostami niszczącymi dach i elewacje. Mieszkańcy często skarżą się na opadłe z drzew liście, które zatykają rynny. Innym problemem związanym z rozłożystymi koronami drzewa są zwierzęta, takie jak kuny, które wspinając się po drzewie dostają się do poszycia dachowego, gdzie niszczą izolację. Poza tym, jesienią duża ilość opadających liści, szczególnie tych o blaszce liściowej dłoniasto-wrębnej i dłoniasto-klapowanej, staje się problemem na niedużej działce (Seneta, 1991).

Większości z tych problemów można uniknąć na etapie projektowania i doboru materiału roślinnego, jeśli do pracy nad projektem terenu zieleni wokół budynku zaangażujemy architekta krajobrazu. W przeciwnym wypadku koszty poprawy sytuacji będą bardzo wysokie. Chodzi tu, na przykład o usługi arborystyczne, pracę z podnośnika koszowego, które i tak nie dają nam gwarancji, że w przyszłości problem się nie powtórzy.

\section{PRZYKŁAD II. ZIELEŃ OSIEDLOWA - CORAZ MNIEJ DRZEW, CORAZ WIĘCEJ BETONU}

W Polsce w latach od 1960 do 1980 powstało wiele budynków z tzw. „wielkiej płyty”, a wokół nich tereny zieleni (głównie trawiastej). Ze względu na wzrastającą liczbę samochodów, pojawiło się przy budynkach zapotrzebowanie na parkingi, a co za tym idzie wiele metrów kwadratowych terenu pełniącego poprzednio funkcję zieleni, pokryto betonem lub kostką betonową. Tutaj bardzo widoczny jest brak współpracy z architektami krajobrazu, brak wiedzy ogrodniczej na temat drzew, które betonuje się dookoła pnia i ogławia.

Kolejny przykład to drzewa nienaturalnie przycięte, tzw. ogławiane (Ryc. 10), które są obecnie częstym widokiem w miastach. 
Ogławianie skutkuje zakłóceniem równowagi fizjologicznej, a w efekcie podatnością na infekcje i szkodniki, co prowadzi do powolnego zamierania drzewa. Nie wspominając już o obniżeniu wartości estetycznej krajobrazu. Z kolei, biorąc pod uwagę aspekty ekologiczne - zachodzi tutaj przede wszystkim zwiększenie erozji gleb i zaburzenie stosunków wodnych (Borowski J., Motas M., 2014). W tym konkretnym przypadku - terenu przy ul. Słowackiego w Goleniowie, drzewa obumarły w ciągu zaledwie jednego roku!!!. Zdjęcie (Ryc. 10 i Ryc. 11) prezentują powyżej po lewej stronie - stan na rok 2020, natomiast zdjęcie po prawej stronie, stan obecny.

Mieszkańcy w obawie przed zagrożeniem bezpieczeństwa, zamawiają firmy świadczące usługi pielęgnacji zieleni, by przyciąć lub usunąć drzewo. W obydwu wypadkach jest to kosztowna usługa angażująca ciężki sprzęt w postaci podnośnika koszowego, pił spalinowych, rębaków i kontenerów na odpady zielone. W ciągu kilku lat w Szczecinie ilość samochodów wyposażonych w podnośniki koszowe wzrosła o kilkaset procent. Obecnie jest już kilkanaście firm, które świadczą usługi podnośnikowe, co świadczy o wysokim zapotrzebowaniu na ogławianie i przycinanie koron drzew.

\section{PRZYKŁAD III. ZIELEŃ PRZYULICZNA - BŁĘDY SA POWTARZANE}

W rozdziale zieleń przyuliczna przedstawiono przykłady z miasta Goleniów, gdzie drzewa rosły w trudnych warunkach miejskich. Jednak warunki te pogorszone zostały znacznie, po odnowieniu nawierzchni chodnika, przy głównej arterii komunikacyjnej tego miasta, czyli ulicy Konstytucji 3 Maja. Starsze, istniejące już drzewa kolejno zostały obudowane wokół pnia kostką betonową, która uniemożliwia dopływ wody, powietrza oraz składników pokarmowych. Poniżej zdjęcie ze stanem na październik 2017 roku (Ryc. 12)

Tutaj natomiast (Ryc. 13) to samo miejsce w Goleniowie i drzewo, z ujęciem zdjęcia pokazującym jak korzenie drzewa, po okresie 3,5 roku, unoszą kostkę betonową w poszukiwaniu wody i powietrza.

Kolejne zdjęcie (Ryc. 14) z lipca 2017 roku, widoczna jest bardzo trudna adaptacja drzewa do nowych, gorszych warunków, związanych z remontem chodnika. Drzewo w lipcu 2017 roku było już w bardzo złej kondycji zdrowotnej. Pogarszający się w krótkim czasie wygląd drzewa jest widoczny po stopniowej redukcji ugałęzienia w koronie drzewa, a następnie pojawiają się wycieki z wnętrza pnia i choroby grzybowe, widoczne na korowinie drzewa.

Zdjęcie poniżej (Ryc. 15, Ryc. 16), przedstawia to samo miejsce lokalizacji drzewa, o którym wspominano wcześniej, z tym że w marcu 2021 roku, nastąpiła wycinka starego drzew, które zastąpiono już nowym, młodszym okazem. Na fotografii nowe drzewo jest oznaczone kolorem czerwonym - patrz Ryc. 15.

\section{METODY PRZESADZANIA DRZEW NOWO NASADZANYCH I DRZEW POMNIKOWYCH}

Tylko w specjalistycznych szkółkach roślin (drzew) wykonuje się tak zwane zabiegi szkółkowania materiału roślinnego, a z tym również zabieg podcinania korzeni (Sobczak 1999). „Szkółkowanie jest to przesadzanie roślin $w$ trakcie produkcji mające na celu rozwinięcie przez nie zwartego systemu korzeniowego, co zapewnia korzystne warunki przyjęcia się rośliny po posadzeniu na miejscu stałym. Rośliny powinny być szkółkowane w odpowiednio dobranej do ich gatunku i odmiany rozstawie. Po zaszkółkowaniu krzewy i drzewa rosną w tym samym pojemniku 1-2 lata, a w gruncie 2-4 lata" (ZSZP, 2018). Drzewa po przeniesieniu w miejsce stałe, trzeba ustabilizować palikami drewnianymi i koniecznie podlać. Stabilizacja drzewa w postaci palików musi pozostać przez 2 lata (Bartosiewicz A. 1977).

Kolejnym czynnikiem wpływającym na szansę przyjęcia się rośliny jest głębokość posadowienia bryły (Ryc. 17). Głębokość dołu na sadzone drzewa powinna odpowiadać wysokości bryły korzeniowej. Drzewo powinno być posadzone na tym samym, a nawet wyższym poziomie, niż rosło wcześniej, tak aby szyjka korzeniowa nie była przykryta ziemią. Dostęp powietrza do strefy korzeniowej musi być zapewniony, wtedy drzewo pozostanie w dobrej kondycji zdrowotnej (Zimmermann A. 2009, p. 369-375). Należy pamietać również, że nadmierne nawilżenie zwłaszcza przy 
glebach gliniastych, również utrudnia dostęp powietrza do korzeni (Ryc. 18). Z kolei, gdy przysypiemy drzewo zbyt grubą warstwą ziemi lub ściółki, zaczyna się ono dusić i wytwarza korzenie otaczające pień (Ellen A. 2000). Każde drzewo niezależnie od wielkości może być przesadzone. U cennych przyrodniczo drzew, posiadających rozległy system korzeniowy, konieczne jest oczyszczenie korzeni z ziemi, wykonane powietrzem pod wysokim ciśnieniem i przygotowanie do transportu. Prace w obrębie systemów korzeniowych drzew są wykonywane urządzeniem AIR SPADE.

Drzewa wysokości do 6 metrów, szkółkowane przez lata w szkółce roślin, mają bryłę korzeniową objętości $1 \mathrm{~m}^{3}$ i ważą ponad tonę. Dlatego drzewo z systemem korzeniowym zregenerowanym w bryle, jest w objętości możliwej do przeniesienia. Nie tylko ogranicza to uszkodzenia systemu korzeniowego, ale też zmniejsza wagę drzewa do transportu i sadzenia. $Z$ tych dwóch metod przesadzania drzew, obie mają wady i zalety. System czyszczenia korzeni drzew stężonym powietrzem, jest bardziej uniwersalny (Ryc. 19, Ryc. 20). W ten sposób możemy przesadzić nawet duże drzewa usytuowane $w$ trudno dostępnych lokalizacjach. Istnieje więc możliwość przesadzania drzew usytuowanych w niewłaściwych miejscach. Natomiast planowanie nowych nasadzeń drzew w mieście i dobór materiału szkółkarskiego powinny być w porozumieniu z wyspecjalizowanymi szkółkami drzewiarskimi, z długoletnim doświadczeniem.

Dobrym rozwiązaniem wydaje się wdrożenie przez władze miasta we współpracy z ogrodnikiem miasta systemu zarządzania zielenią miejską, gdzie zewidencjonowane będą wszystkie wartościowe okazy drzew. System taki oparty na technologii GIS może zawierać informacje o stanie zdrowotnym, wieku każdego drzewa oraz o zakresie i terminach przeprowadzonych prac pielęgnacyjnych. Ewidencja i stała kontrola nad najważniejszymi zasobami zieleni miasta, może również umożliwić precyzyjną i profesjonalną opiekę nad drzewami. W Nowym Jorku system ewidencji drzew ulicznych, już istnieje. Jest to najdokładniejsza i najbardziej szczegółowa mapa drzew miejskich na świecie.

\section{POZYTYWNE PRZYKŁADY NASADZEŃ WYSOKICH DRZEW W PRZESTRZENI MIEJSKIEJ}

Grupa drzew i krzewów, których zdjęcie przedstawiono poniżej posiada dostateczną przestrzeń wokół i tym samym odpowiednie warunki do rozwoju i wzrostu.

Drzewa usytuowane przy pasie zieleni przy jednym z centów handlowych w Szczecinie (Ryc. 21) są w naprawdę dobrej kondycji zdrowotnej. Oprócz czynnika, którym w tym wypadku jest duża przestrzeń wokół pnia, jest to zauważalny delikatny, minimalny spadek i obniżanie się terenu trawnika w kierunku nasadzeń roślinnych. Spadek terenu powoduje, że przy każdorazowym większym lub mniejszym opadzie deszczu, woda transportowana jest wprost pod roślinność. Drzewa z roku na rok są coraz większe. Oprócz wcześniej wspomnianego spadku terenu i dużej przestrzeni wokół roślin, zamontowano również barierki w celu zapobiegania udeptywaniu mechanicznym gleby wokół roślin. Kolejnym przykładem jest ul. Bolesława Krzywoustego w Szczecinie, gdzie wzdłuż wspomnianej ulicy znajduje się pas zieleni. Wygląd drzew tam rosnących świadczy o odpowiednim doborze gatunkowym roślin i wyborze obsadzenia ulicy w formie pasa zieleni. Drzewa przy ulicy Bolesława Krzywoustego rosną w metalowych kratkach, ale często są też sadzone w sąsiedztwie krzewów, gdzie jest swobodny dostęp wody i powietrza do korzeni drzew (Ryc. 22).

$\mathrm{Na}$ archiwalnej fotografii z 1908 roku (Ryc. 23), ukazującej widok na opisaną wyżej ulicę Konstytucji 3 Maja w Goleniowie, w prawym dolnym rogu widać drzewa. Drzewa w tamtym okresie maja dostateczne warunki, aby mogły prawidłowo się rozwijać. Ciąg pieszy sąsiaduje z wyznaczonym pasem zieleni wysokiej.

Poniżej zdjęcie oraz rzut z góry na ul. Konstytucji 3 Maja, które pokazują, że odległość od środka jezdni do linii zabudowy to około 8,5 m (Ryc. 24, Ryc. 25). Wynika z tego, że szerokość istniejącego ciągu pieszego, wciąż pozwala na wprowadzenie istniejących już drzew wraz z pasem zieleni w projekt przebudowy ulicy. 


\section{WNIOSKI}

Na podstawie przeprowadzonych badań i analiz można sformułować wnioski, które mogą przyczynić się do poprawy obecnej, często niekorzystnej sytuacji drzew wysokich w przestrzeni miejskiej.

1. Od dłuższego czasu, trwa ciągła redukcja przestrzeni wokół drzew. Tymczasem, niektóre gatunki drzew potrzebują przestrzeni, jeśli w naturze tworzą szerokie malownicze korony.

2. Konieczny jest odpowiedni dobór gatunkowo-odmianowy drzew w miastach.

3. Ważne jest, aby zawsze poznać istotę problemu, zadając jak najwięcej pytań, odnajdując odpowiedzi. Dlaczego drzewo nie rośnie? Należy podejmować próby zrozumienia problemu w całej jego złożoności, ponieważ nigdy nie występuje tylko jeden czynnik, który decyduje o zdrowym wzroście i rozwoju drzewa.

4. Zapewnienie roślinom minimalnych, korzystnych warunków rozwoju nie musi wiązać się z bardzo wysokim budżetem i zastosowaniem najnowszych technologii budowlanych. Inteligentne rozwiązania problemów, to często proste rozwiązania zastosowane w odpowiednim momencie, na etapie procesu planowania. Na przykład: wyprofilowanie terenu i ustalenie kierunku spływu wód opadowych, sadzenie roślin w większych grupach, brak redukcji przestrzeni powierzchni chłonnej wokół korzeni starszych, w szczególności pomnikowych drzew, czy też sadzenie drzew o większym obwodzie pnia.

5. Traktowanie jako niezbędnego schematu wyraźnego i równorzędnego podziału: na pas jezdny, pas zieleni i pas pieszy w ciągu komunikacyjnym.

6. W związku z dynamicznym rozwojem miast, infrastruktury drogowej, miejsc wypoczynku, a także koniecznością ochrony krajobrazu, przy powstających planach zagospodarowania przestrzennego konieczna staje się ścisła współpraca architekta, architekta krajobrazu, ogrodnika i specjalistów wielu innych branż.

7. Brak drzew i rozległe utwardzone powierzchnie (często betonowe place) są wyraźnie negatywnie odczuwalne dla człowieka w gorące, upalne dni i nie tylko. Zieleń wysoka daje wiele korzyści, m. in.: cień, bioróżnorodność, przyjemny mikroklimat, chroni przed zanieczyszczeniami pyłowymi, dymem, itp.

8. Podczas realizacji nowych projektów lub modernizacji istniejących przestrzeni miejskich, które zakładają wprowadzenie ponad kilkudziesięciu procent powierzchni utwardzonej (betonowej), komfort życia w mieście bardzo się pogorsza. Drzewa przyczyniają się do polepszenia atrakcyjności i jakości życia w mieście, dlatego zachowanie i ochrona drzew w przestrzeni miejskiej powinna stać się priorytetem.

9. Drzewa są również ważną częścią naszego krajobrazu kulturowego i przyrodniczego i także z tego względu powinny podlegać ochronie w krajobrazie miasta, wsi, czy też terenów otwartych.

\section{PODSUMOWANIE}

Problematyczne sytuacje, przyszłe kolizje struktury zabudowy, jako „tkanki miejskiej”, poprzez zmiany struktury funkcjonalno-przestrzennej, z miejską przestrzenią zieleni, można kontrolować na etapie projektowania. Kształtuje się w ten sposób, otaczające miejskie tereny zieleni. Odpowiedni dobór materiałów, nie tylko tych budowlanych, ale materiału roślinnego, które w rękach dobrego projektanta, na pewno będą miały wpływ na wzrost atrakcyjności przestrzeni miejskiej dla przyszłych pokoleń. W miastach przykłady braku zaangażowania w proces projektowy i wykonawczy, specjalistów praktykujących prace związane z ochroną i rozwojem terenów zieleni, mnożą się, a efekty niestety mierne, widać. Często związane jest to przede wszystkim z braku wiedzy, a nie z braku w budżecie. 


\section{BIBLIOGRAPHY}

Arnold. H. F. 1980. Trees in Urban Design. New York, New York: Van Nostrand Reinhold Company.

Bartosiewicz A. Urządzanie terenów zieleni. 1977. Wydawnictwo Szkolne i Pedagogiczne, Warszawa

Benckini R. COMPANY Large tree transplanting. http://benckini.com/tree-transplanting, dostęp/access 201703-03

Beyer KMM, Kaltenbach A, Szabo A, Bogar S, Nieto FJ, Malecki KM (2014) Exposure to neighborhood green space and mental health: evidence from survey of the health of Winsconsing. Int $\mathrm{J}$ Environ Res Public Health 11:3453-3472

Borowski J., Motas M. 2014. Podstawy pielęgnacji drzew. Drzewa w krajobrazie. Podręcznik praktyka.(red) Witkoś-Gnach K. i Tyszko-Chmielowiec P., Wrocław.

Bugała W., 2000. Drzewa i krzewy. Państwowe Wydawnictwo Rolnicze i Leśne, Warszawa.

Bugała W., Chylarecki H., Bojarczuk T. 1984. Dobór drzew i krzewów do obsadzania ulic, placów i w miastach z uwzględnieniem kryteriów rejonizacji. Arboretum Kórnickie.

Crabtree P. 2020. Trees in urban design. https://www.cnu.org/sites/default/files/trees_in_urban_design.pdf, dostęp/access 2021-03-03

Czekiel-Świtalska E., Rola zieleni w mieście na przykładzie centrum szczecina „Przestrzeń i Forma”, 2010, no.13, p. 165-182.

Ellen A. Vincent. 2000. Show me your root flare! www.clemson.edu/cafls/vincent/articles/show_me_your_root_flare.pdf, dostęp/access 2020-03-03

Ely M. 2009. Planning for trees in urban environments. Proceedings of the 10th National Street Tree Symposium 2009. p. 87-98

F. Ferrini, F. Bussotti, M. Tattini, A. Fini. 2014. Trees in the urban environment: response mechanisms and benefits for the ecosystem should guide plant selection for future plantings. Agrochimica International Journal of Plant Chemistry, Soil Science and Plant Nutrition of the University of Pisa. p. 243

FOTOPOLSKA. https://www.fotopolska.eu/1138853,foto.html, dostęp/access 2021-03-03

Howe D. 2009. https://takingplaceinthetrees.net/2009/08/07/air-tool-observations/, dostęp/access 2017-03-03

Ken Salwail. www.kelownagardens.com, dostęp/access 2017-03-03

LMC. www.Imchouston.com, dostęp/access 2017-03-03

Lüttge U. Buckeridge M. 2020. Trees: structure and function and the challenges of urbanization. SpringerVerlag GmbH Germany, part of Springer Nature 2020

Polińska B. i Gaj J., 2016. Prace na byłym cmentarzu przy ulicy Wojska Polskiego w końcu rozpoczęte! 29.10.2016. http://www.bialygrosz.goleniow.pl/index.php/artykuly/aktualnosci/prace-na-bylym, dostęp/access 20-01-2020.

PROGRAM PLATAN. https://www.szczecin.eu/pl/zielone-miasto/platan, dostęp/access 17-01-2021

Seneta. 1991. Drzewa i krzewy liściaste A-B. Wydawnictwo Naukowe PWN, Warszawa.

Sobczak R., 1999. Szkółkarstwo leśne, ozdobne, i zadrzewieniowe. Collective work. Oficyna Edytorska „Wydawnictwo Świat”, Warszawa.

Taking www.takingplaceinthetrees.net dostęp/access 17-01-2021

Uchwała nr XIV/320/11 RM Szczecin. Strategia Rozwoju Szczecina 2025 z dnia 19 grudnia 2011r.

Ustawa z dnia 16 kwietnia 2004 r. o ochronie przyrody. (2021) Dziennik Ustaw Rzeczypospolitej Polskiej, item 142, 30 March 2021

William F. Hunt, III and Eban Z. Bean. 2006. NC STATE UNIVERSITY PERMEABLE PAVEMENT RESEARCH AND CHANGES TO THE STATE OF NC RUNOFF CREDIT SYSTEM

Zarządzenie Nr 140/21 Prezydenta Miasta Szczecin, z dnia 23 marca $2021 \mathrm{r}$.

ZBILK. Program Zielone Przedogródki Szczecina - program realizowany przez Zarząd Budynków i Lokali Komunalnych w 2017. http://zbilk.szczecin.pl/systemfiles/articlefiles/515/(20150108.094519).zielone_przedogrodki_szczecin_regulamin . pdf dostęp/access 17-01-2021

Zimmermann A. 2009. Constructing Landscape, Materials, Techniques, Structural Components Birkhauser Verlag AG 
Zimmermann M.H., Brown C. L. 1981. Drzewa struktura i funkcje. PWN, Warszawa.

ZSZP. 2018. Związek Szkółkarzy Polskich, Zalecenia jakościowe dla ozdobnego materiału szkółkarskiego -

wydanie III poprawione i uzupełnione. Dostęp poprzez: https://zszp.pl/wp-

content/uploads/2018/10/zalecenia2018.pdf

ZUK. https://zuk.szczecin.pl/dzialalnosc/zielen-miejska/informacje-ogolne, dostęp/access 17-01-2021.

\section{ABOUT THE AUTHOR}

Paweł Nowak works as an adjunct professor at the Chair of Landscape Architecture of the Faculty of Environmental Management and Agriculture of the West Pomeranian University of Technology in Szczecin. He is a doctor of the technical sciences specialising in architecture and urban planning (Wrocław University of Science and Technology, Faculty of Architecture, 2012). He teaches students of the Spatial Management and Landscape Architecture courses. The scope of teaching covers general and detailed spatial planning. He uses digital technologies in his design work to analyse data, draft plans and design the landscape.

\section{O AUTORZE}

Paweł Nowak pracuje jako adiunkt w Katedrze Projektowania Krajobrazu na Wydziale Kształtowania Środowiska i Rolnictwa Zachodniopomorskiego Uniwersytetu Technologicznego w Szczecinie. Jest doktorem nauk technicznych w zakresie architektury i urbanistyki (Politechnika Wrocławska, Wydział Architektury w roku 2012). Prowadzi zajęcia na kierunkach: Gospodarka Przestrzenna, Architektura Krajobrazu. Zakres nauczania obejmuje planowanie przestrzenne ogólne i szczegółowe. W pracy projektowej wykorzystuje techniki komputerowe przy analizie danych, planowaniu przestrzennym i projektowaniu krajobrazu.

Contact | Kontakt: Pawel.Nowak@zut.edu.pl 